\title{
Edible Insects in Africa in Terms of Food, Wildlife Resource, and Pest Management Legislation
}

\author{
Nils Th. Grabowski ${ }^{1, *}$, Séverin Tchibozo ${ }^{2} \oplus$, Amir Abdulmawjood ${ }^{3}$, Fatma Acheuk ${ }^{4}$, \\ Meriem M'Saad Guerfali ${ }^{5}{ }^{(1)}$, Waheed A.A. Sayed ${ }^{6}{ }^{(i)}$ and Madeleine Plötz ${ }^{1}$ \\ 1 Institute for Food Quality and Food Safety, Hannover University of Veterinary Medicine, Foundation, \\ Bischofsholer Damm 15, D-30173 Hannover, Germany; Madeleine.Ploetz@tiho-hannover.de \\ 2 Research Centre for Biodiversity Management, 04 B.P., Cotonou BJ-0385, Benin; tchisev@yahoo.fr \\ 3 Institute for Food Quality and Food Safety, Research Center for Emerging Infections and Zoonoses (RIZ), \\ Hannover University of Veterinary Medicine, Foundation, Bünteweg 2, D-30559 Hannover, Germany; \\ amir.abdulmawjood@tiho-hannover.de \\ 4 Laboratory of Valorization and Conservation of Biological Resources, University of M'Hamed Bougara of \\ Boumerdes, Avenue de l'indépendance, Boumerdès DZ-35000, Algeria; fatma.acheuk@yahoo.fr \\ 5 Laboratory of Biotechnology and Nuclear Technologies LR16CNSTN01, National Centre for Nuclear \\ Sciences and Technology, Technopole de Sidi Thabet, Sidi Thabet T-2020, Tunisia; msaad_tn@yahoo.fr \\ 6 Biological Application Department, Nuclear Research Centre, Atomic Energy Authority, Cairo ET-11787, \\ Egypt; waheedel@hotmail.com \\ * Correspondence: Nils.Grabowski@tiho-hannover.de
}

Received: 4 March 2020; Accepted: 13 April 2020; Published: 16 April 2020

check for updates

\begin{abstract}
Entomophagy is an ancient and actually African tradition that has been receiving renewed attention since edible insects have been identified as one of the solutions to improve global nutrition. As any other foodstuff, insects should be regulated by the government to ensure product quality and consumer safety. The goal of the present paper was to assess the current legal status of edible insects in Africa. For that, corresponding authorities were contacted along with an extensive online search, relying mostly on the FAOLEX database. Except for Botswana, insects are not mentioned in national regulations, although the definitions for "foodstuff" allow their inclusion, i.e., general food law can also apply to insects. Contacted authorities tolerated entomophagy, even though no legal base existed. However, insects typically appear in laws pertaining the use of natural resources, making a permit necessary (in most cases). Pest management regulation can also refer to edible species, e.g., locusts or weevils. Farming is an option that should be assessed carefully. All this creates a complex, nation-specific situation regarding which insect may be used legally to what purpose. Recommendations for elements in future insect-related regulations from the food hygiene point of view are provided.
\end{abstract}

Keywords: entomophagy; food law; Africa; food hygiene; food policy

\section{Introduction}

\subsection{Entomophagy on the African Continent}

Some years ago, the FAO (Food and Agricultural Organization of the United Nations) recognized the potential of edible insects as one possibility to mitigate hunger and the effects of the climate change, and as a response to that, the discussion of establishing insect farms in traditionally entomophagous countries rather than increasing the extraction from the wild started [1].

Edible insects have been part of the human diet from the dawn of mankind on. However, food habits changed over the millennia, and while consuming insects was largely lost in Europe 
after the classical antiquity, the tradition lingered on in Africa. There are hundreds of insect species consumed in Africa as foodstuffs or as traditional medicine [1-6]. The awareness of the benefits of edible insects has also reached non-traditional sectors of the African population, and web-based information sites like LINCAOCNET (http://gbif.africamuseum.be/lincaocnet_dev/) provide searchable information on local species.

Insects are traded in a relatively small to medium level. The economic benefit varies with the species and is seldom accounted for, but one of the most significant ones seems to be the phane caterpillars of a saturniid emperor moth Gonimbrasia belina (ex "Imbrasia belina"), reaching a yearly trade value of more than $\$ 85$ million in Southern Africa.

Like with any other foodstuff, the consumption of edible insects may lead to consumer risks, typically allergens, foodborne diseases, food spoilage agents, and contaminants [7]. Being so, the tradition has developed a set of dos and do nots to ensure food safety to a certain degree. However, as traditions develop over long periods of time and tend to become inflexible, some parts of it may not cover "modern" risks like environmental pollution, or even packaging [3]. In fact, the traditional handling of African insect-based products has become submitted to scientific research, and results show that even processed products may contain pathogens. By means of illustration (and far beyond completeness of data), Table 1 provides a look into the microbiology of fresh and processed products from three African insect species.

Table 1. Selection of microbiological findings in three African edible insect species (African mole cricket (Gryllotalpa africana), cabbage tree emperor moth (Bunaea alcinoe), and African palm weevil (Rhynchophorus phoenicis)); based on [1]. Blank spaces either mean that the sample was negative for that pathogen or was not tested for it.

\begin{tabular}{|c|c|c|c|c|c|c|c|c|c|c|c|c|c|c|c|c|c|}
\hline Species & Product & 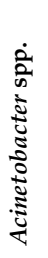 & 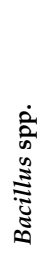 & 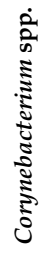 & 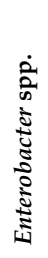 & 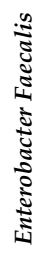 & 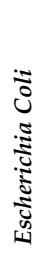 & 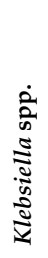 & 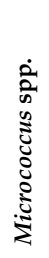 & 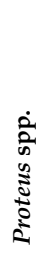 & 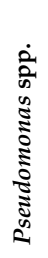 & 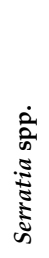 & 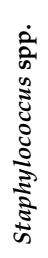 & 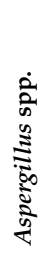 & 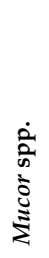 & 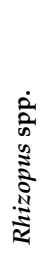 & 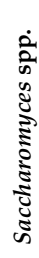 \\
\hline Bunaea alcinoe & Larva, raw & + & + & & & & & & + & & & & + & & & & \\
\hline \multirow{4}{*}{$\begin{array}{l}\text { Rhynchopho-rus } \\
\text { phoenicis }\end{array}$} & Skin & & + & & & & & + & & & + & + & + & & & & + \\
\hline & Gut & & + & & + & & & & & & & + & + & & & & \\
\hline & Larva, fresh & & + & & + & & & & & & & + & + & & & & \\
\hline & Larva, fried & & + & & & & & & & & & & + & & & & \\
\hline
\end{tabular}

These results suggest that a stricter control of insect-based products is needed, moreover, if insect entrepreneurs and/or consumers lose this traditional knowledge. Implementing food legislation is a proven method to reduce food-related consumer risks.

\subsection{The European Union as a Starting Point for Legal Considerations}

In Europe and in terms of food legislation, a division can be made between EU member and non-member states, and within the EU, between EU law and national law. These food laws, along with a large number of related legal texts, represent the base of public health control of foodstuffs. It covers all the productions steps of the food chain from the primary production to the purchase of the product by the consumer. With the EU, community and national legislation was harmonized largely to pursue a maximum of congruency among laws and a minimum of features regulated twice (i.e., on EU and national level). The system has been established for the ordinary animal-derived foodstuffs and is in constant revision and improvement.

Europe is one of those geographical areas with no recent entomophagy tradition (despite some exceptions), and the discussion is moreover addressing the feasibility and the practical and legal 
framework to establish insect farms. This created a dilemma, because on one hand, entrepreneurs that wish to start an insect business depend on the certification by corresponding authorities. On the other hand, in many countries, insects are neither expressly allowed nor forbidden. So, there is no legal framework by which these authorities could certify this enterprise, even if there is good will to promote this development. Thus, authorities ask the entrepreneurs for more information on risk handling, etc., which in turn can only generate once the business is running. This creates a climate of legal uncertainty, which is perceived as obstacles by the insect business operators [8,9].

However, this is changing. In 2015, the EFSA (European Food Safety Authority) published the Risk profile related to production and consumption of insects as food and feed, coming to the overall conclusion that, when produced according to current law requirements, insects do not pose a major risk to consumers. However, knowledge on residues and contaminants was scarce, and EFFSA recommended more research. The second important EU publication is the amendment of the novel food regulation, i.e., $R E G$ (EC) 2015/2283. In it, insects are clearly classified as potential foodstuffs, but for each species and product, a separate authorization procedure must be followed, leading to the inclusion of the novel foodstuff in the so-called Union List. At present, there are several requests, which are being processed. Although this regulation does not contain specific requirements for insects as foodstuffs (e.g., primary production, processing, quality parameters, etc.), this regulation provides the base for a clearer, EU-wide regulatory frame for all sectors involved in insect production.

Finally, there is draft Ref. Ares (2019) 382900-23/01/2019, which proposes to add another Appendix A, specific for edible insects to the REG (EC) 853/2004. This regulation contains all regulatory issues about the production of animal-based foodstuffs along the production chain. The draft contains a definition of "insect" and proposals on the choice of allowed feedstuffs in insect farming. It has, however, not been ratified so far.

Until then, several nations issued national guidelines, which should be regarded as recommendations and interim solutions. However, there is a marked degree of heterogeneity in this process on the continent, ranging from utter rejection to a relatively developed legal framework to produce, sell, and monitor insect-based foodstuffs (IBF). In addition, not all European nations have issued official statements regarding edible insects so that for those countries, a grey zone is presumed. This current European situation is described in [7].

\subsection{African Countries and Economic Communities}

Africa, as all other continents, is a spectacular mixture of ethnic groups, languages (approximately 2000), religions, lifestyles, and cultures, subsuming into more than 1.3 billion humans inhabiting it. All African states are part of the African Union (AU). Within it, the African Economic Community (AEC) is the common organization seeking, ultimately, economic and monetary union of the member states, which vaguely corresponds to the EU. AU/AEC recognize several, so-called Regional Economic Communities (REC), some of which have subgroups, i.e.,

- Arab Maghreb Union (UMA);

- Common Market for Eastern and Southern Africa (COMESA);

- Community of Sahel-Saharan States (CEN-SAD);

- East African Community (EAC);

- Economic Community of Central African States (ECCAS), with CEMAC (Economic and Monetary Community of Central Africa) as subgroup;

- Economic Community of West African States (ECOWAS), with UEMOA (West African Economic and Monetary Union) and WAMZ (West African Monetary Zone) as subgroups; the latter does not address specific food or agriculture issues and is therefore not considered here;

- Intergovernmental Authority on Development (IGAD);

- Southern African Development Community (SADC), with SACU (South African Customs Union) as a subgroup. 
However, most subgroups are not recognized by AEC (CEMAC, SACU, and UEMOA), and there are other trade unions that also lack recognition by AEC, i.e., the Economic Community of Great Lakes Countries (CEPGL), Indian Ocean Commission (IOC), and Mano River Union (MRU).

Finally, there are trade blocks that include both African and non-African nations. One example is GAFTA, the Greater Arab Free Trade Area, which originates from the Arab League and includes most Arabic-speaking countries inside and outside Africa. IOC is an organization that links African island nations with France via this country's oversea regions. Table 2 subsumes the affiliation of the African nations to these trading communities. It reveals a complex network of interactions between the different African nations.

Table 2. Affiliations of African nations to the different trading blocks. See text for abbreviations. Blocks not addressing food issues were excluded.

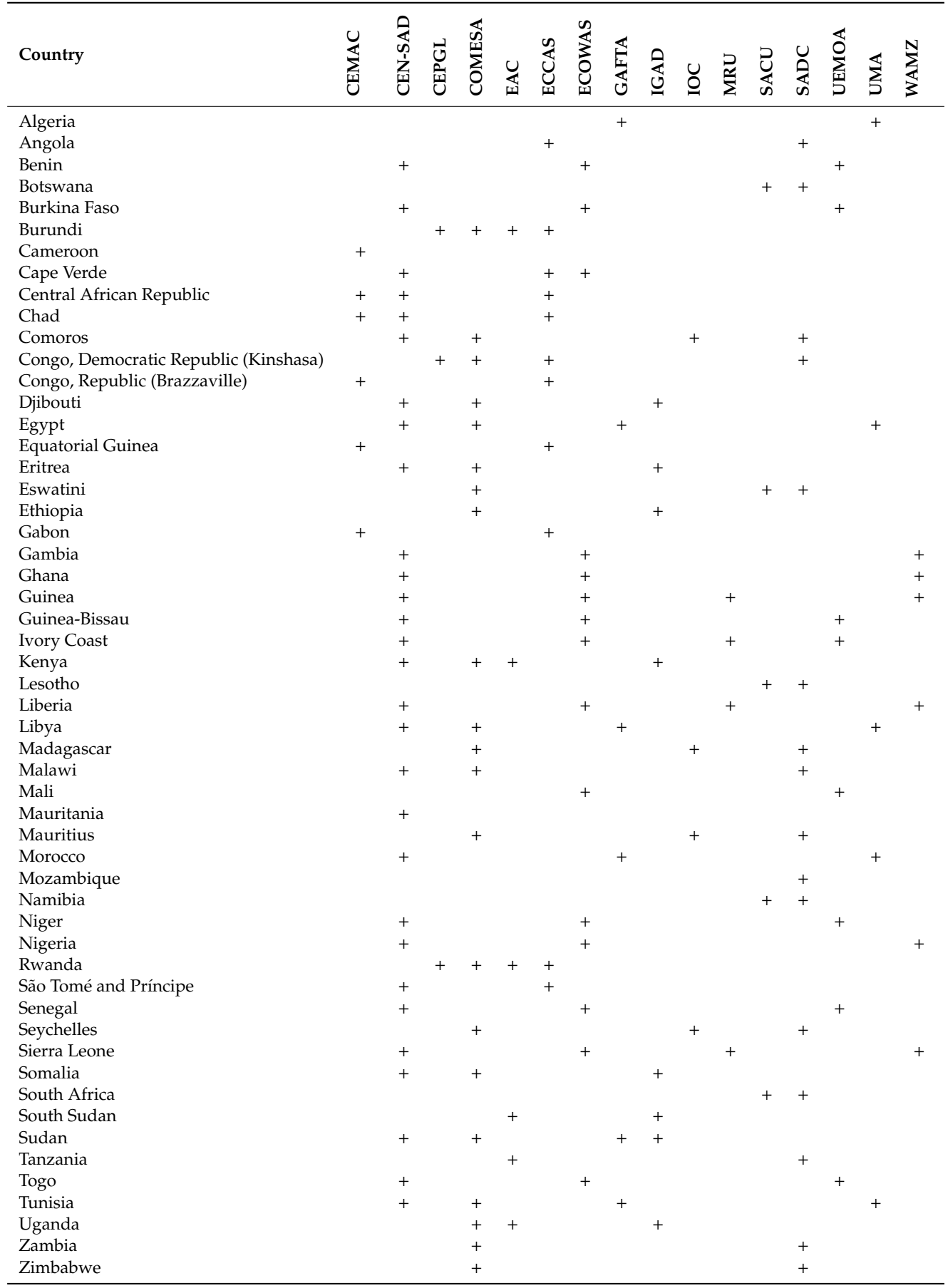


Regardless of the official status at AU/AEC, these trade blocks have the goal to improve the trade among the member states, creating free trading zones. The trade also includes foods, and just like many European countries, African countries face the problem of trading foodstuffs with different quality standards. Another of the challenges these blocs have is the fact that many African countries belong to the more than one trading block, and the activity of these blocks varies. Some of these blocks have issued common trade rules that can be read in the internet, and some do not.

Besides international rules, national food law and other regulations also a play a very important role, particularly for foodstuffs produced and consumed inside the corresponding countries. The extent of this legislation varies strongly among them.

The aim of this contribution is to outline the current legal situation regarding edible insects in all African countries.

\section{Material and Methods}

For this research, all African countries were included (Table 2). Not entering a political dispute, states not recognized by the United Nations (typically "break-away states") were included if five or more UN nations recognized them as independent. In this way, Galmudug, Khaatumo, Puntland, Republic of Azania, and the Republic of Somaliland were not considered in this survey, while the Sahrawi Arab Democratic Republic was. However, no data for the latter could be encountered, so no further mention of this country would be made.

Initially, an approach similar that made for the publication regarding the legal status in Europe $[7,10]$ was intended, i.e., contacting the competent authorities (Table 3) personally by telephone and/or mail. However, the degree of response varied strongly among countries, with the best replies from the most French-speaking and Arabic-speaking countries. Others did not respond (even after contacting the corresponding embassies in Europe), even after several attempts, and so their homepages were searched for corresponding regulations. As this was not successful in some of them, the FAOLEX page (http://www.fao.org/faolex/country-profiles/en/) was consulted, trusting in having the most complete and updated database for FAO-related legislations. Eventually, all nations were checked by this mean. In some cases, additional information was found in secondary sources, e.g., Droit-Afrique.com, but there is a possible bias because these regulations may not be reflecting the actual situation of the given country. Data was gathered between the fall of 2018 and that of 2019.

Table 3. List of African countries and authorities that provided information on the legal status of edible insects including the amount of edible species per countries according to Jongema [11]; besides these country-specific data, 4 species were recorded for Northern, 91 for central, 2 for Western, 9 for Eastern, and 20 for Southern Africa.

\begin{tabular}{|c|c|c|}
\hline Country & Institution & REIS * \\
\hline Algeria & $\begin{array}{l}\text { وزارة الفلاحة و التنمية الريفية و الصيد البحري } \\
\text { (Ministry of Agriculture, Rural Development and Fisheries) }\end{array}$ & 0 \\
\hline Angola & $\begin{array}{l}\text { MINAGRIF-Ministério da Agricultura e Florestas } \\
\text { (Ministry of Agriculture and Forests) }\end{array}$ & 16 \\
\hline Benin & $\begin{array}{l}\text { ABSSA-Agence Béninoise de Sécurité Sanitaire des Aliments } \\
\text { (Beninese Agency for the Sanitary Security of Foodstuffs) }\end{array}$ & 24 \\
\hline Botswana & Ministry of Health & 22 \\
\hline Burkina Faso & $\begin{array}{l}\text { Ministère de l'Agriculture et des Aménagements Hydrauliques } \\
\text { (Ministry of Agriculture and Water Engineering) }\end{array}$ & 7 \\
\hline Burundi & $\begin{array}{l}\text { Ministère de l'Agriculture et de l'Élevage } \\
\text { (Ministry of Agriculture and Livestock Breeding) }\end{array}$ & 1 \\
\hline Cameroon & $\begin{array}{l}\text { MINADER-Ministère de l'Agriculture et du Développement Rurale } \\
\text { (Ministry of Agriculture and Rural Development) }\end{array}$ & 59 \\
\hline
\end{tabular}


Table 3. Cont

\begin{tabular}{|c|c|c|}
\hline Country & Institution & REIS * \\
\hline Cape Verde & $\begin{array}{l}\text { Ministério da Agricultura e Ambiente } \\
\text { (Ministry of Agriculture and Environment) }\end{array}$ & 0 \\
\hline Central African Republic & $\begin{array}{l}\text { Ambassade de la République Centrafricaine à Paris } \\
\text { (Embassy of the Central AfricanRepublic in Paris) }\end{array}$ & 54 \\
\hline Chad & Ministère de la Production, de l'Irrigation et des Equipements Agricoles & 1 \\
\hline Comoros & $\begin{array}{l}\text { Ministère de l'Agriculture, de la Pêche, de l'Environnement, } \\
\text { de l'Aménagement du Territoire et de l'Urbanisme } \\
\text { (Ministry of Agriculture, Fishery, Environment, Land Use Planning, } \\
\text { and Urbanization) }\end{array}$ & 0 \\
\hline $\begin{array}{l}\text { Congo, Democratic Republic } \\
\text { (Kinshasa) }\end{array}$ & $\begin{array}{l}\text { Ministère de l'Agriculture de l'Élevage et de la Pêche de la République } \\
\text { Démocratique du Congo (Ministry of Agriculture, Livestock Breeding, } \\
\text { and Fishery of the Democratic Republic of the Congo) }\end{array}$ & 107 \\
\hline Congo, Republic (Brazzaville) & $\begin{array}{l}\text { Ministère de l'Agriculture de l'Élevage et de la Pêche } \\
\text { (Ministry of Agriculture, Livestock Breeding, and Fishery) }\end{array}$ & 59 \\
\hline Djibouti & $\begin{array}{l}\text { MAEM-Ministère de l'Agriculture, de l'Elevage et de la Mer, Chargé } \\
\text { des Ressources Hydrauliques (Ministry of Agriculture, Livestock, \& } \\
\text { Fisheries, in charge of water resources) }\end{array}$ & 0 \\
\hline Egypt & $\begin{array}{l}\text { وزارة الزراعة وإستصلاح الأراضي } \\
\text { (Ministry of Agriculture and Reclamation of Land) }\end{array}$ & 1 \\
\hline Equatorial Guinea & $\begin{array}{l}\text { Ministerio de Agricultura y Bosques } \\
\text { (Ministry of Agriculture and Forests) }\end{array}$ & 1 \\
\hline Eritrea & $\begin{array}{l}\text { Botschaft des Staates Eritrea in der Bundesrepublik Deutschland } \\
\text { (Embassy of the State of Eritrea in the Federal Republic of Germany) }\end{array}$ & 0 \\
\hline Eswatini & Ministry of Agriculture & 20 \\
\hline Ethiopia & 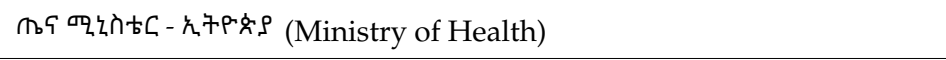 & 1 \\
\hline Gabon & $\begin{array}{l}\text { Ministère de l'Agriculture, de l'Elevage, chargé de la mise en œuvre du } \\
\text { programme Graine (Ministry of Agriculture, Livestock Breeding, } \\
\text { in charge of carrying out the Graine program) }\end{array}$ & 11 \\
\hline Gambia & FSQA-Food Safety and Quality Authority & 1 \\
\hline Ghana & FDA-Food Safety Division & 3 \\
\hline Guinea & Ministère de l'Agriculture (Ministry of Agriculture) & 9 \\
\hline Guinea-Bissau & $\begin{array}{l}\text { Ministério da Agricultura e Desenvolvimento Rural } \\
\text { (Ministry of Agriculture and Rural Development) }\end{array}$ & 2 \\
\hline Ivory Coast & $\begin{array}{l}\text { Ministère de l'Agriculture et du Dévelopment Rural } \\
\text { (Ministry of Agriculture and Rural Development) }\end{array}$ & 5 \\
\hline Kenya & Ministry of Agriculture, Livestock and Fisheries & 10 \\
\hline Lesotho & Ministry of Agriculture and Food Security & 20 \\
\hline Liberia & MOA-Ministry of Agriculture & 2 \\
\hline Libya & $\begin{array}{l}\text { وزارة الزراعة والثروة الحيوانية والبحرية } \\
\text { (Ministry of Agriculture, Fisheries, Livestock, and Irrigation) }\end{array}$ & 1 \\
\hline Madagascar & $\begin{array}{l}\text { MAEP-Ministère de l'Agriculture, de l'Elevage et de la Pêche } \\
\text { (Ministry of Agriculture, Animal Breeding and Fishery) }\end{array}$ & 34 \\
\hline Malawi & Ministry of Agriculture, Irrigation, and Water Management & 20 \\
\hline Mali & $\begin{array}{l}\text { MEADD-Ministère de l'Environnement, de l'Assainissement } \\
\text { et du Développement Durable (Ministry of Environment, } \\
\text { Water Treatment, and Sustainable Development) }\end{array}$ & 8 \\
\hline
\end{tabular}


Table 3. Cont

\begin{tabular}{|c|c|c|}
\hline Country & Institution & REIS * \\
\hline Mauritania & $\begin{array}{l}\text { (Ministry of Rural Development) } \\
\text { (وزارة التنمية الريفية/Ministère de Développement Rural }\end{array}$ & 0 \\
\hline Mauritius & Ministry of Agro Industry and Food Security & 2 \\
\hline Morocco & $\begin{array}{l}\text { /وزارة الفيلاحة والصيد الباحري والتينمية القريية والميجاه والغابات } \\
\text { Ministère d'Agriculture, de la Pêche Maritime, du Développement } \\
\text { Rural, et des Eaux et Forêts (Ministry of Agriculture, Fishery, } \\
\text { Rural Development, Water and Forests) }\end{array}$ & 2 \\
\hline Mozambique & $\begin{array}{l}\text { SETSAN-Secretariado Técnico de Segurança Alimentar e Nutricional } \\
\text { (Technical Secretariate of Food and Nutrition Safety) }\end{array}$ & 3 \\
\hline Namibia & Ministry of Agriculture, Water, and Forestry & 27 \\
\hline Niger & Ministère de l'Èlevage (Ministry of Animal Breeding) & 19 \\
\hline Nigeria & $\begin{array}{l}\text { NAFDAC-National Agency for Food and Drug Administration } \\
\text { and Control }\end{array}$ & 19 \\
\hline Rwanda & MINAGRI—Ministère de l'Agriculture (Ministry of Agriculture) & 0 \\
\hline São Tomé and Príncipe & $\begin{array}{l}\text { MADR-Ministério da Agricultura e Desenvolvimento Rural } \\
\text { (Ministry of Agriculture and Rural Development) }\end{array}$ & 4 \\
\hline Senegal & $\begin{array}{l}\text { Ministère de l'Agriculture et de l'Équipement Rural } \\
\text { (Ministry of Agriculture and Rural Supply) }\end{array}$ & 10 \\
\hline Seychelles & Ministry of Fisheries and Agriculture & 0 \\
\hline Sierra Leone & Ministry of Agriculture, Forestry and Food Security & 7 \\
\hline Somalia & $\begin{array}{l}\text { Wasaaradda Beerahaiyo Waraabka } \\
\text { (Ministry of Agriculture and Irrigation) }\end{array}$ & 0 \\
\hline South Africa & FACS—Food Advisory Consumer Service & 58 \\
\hline South Sudan & Ministry of Agriculture and Forestry & $1^{* *}$ \\
\hline Sudan & $\begin{array}{l}\text { وزارة الثروة الحيوانية و السمكية و المرايي } \\
\text { (Ministry of Livestock, Fisheries, and Rangeland) }\end{array}$ & $7^{* *}$ \\
\hline Tanzania & Ministry of Livestock and Fisheries & 22 \\
\hline Togo & $\begin{array}{l}\text { Ministère de l'Agriculture, de la Production Animale et de l'Halieutique } \\
\text { (Ministry of Agriculture, Animal Breeding, and Fishery) }\end{array}$ & 14 \\
\hline Tunisia & وزارة الفلاحة (Ministry of Agriculture) & 0 \\
\hline Uganda & MAAIF-Ministry of Agriculture, Animal Industry, and Fisheries & 8 \\
\hline Zambia & Ministry of Agriculture & 75 \\
\hline Zimbabwe & Ministry of Lands, Agriculture, Water, Climate and Rural Resettlement & 47 \\
\hline
\end{tabular}

Resources considered in this paper were publications from the AU and other trade blocks detailed in Table 2 and regulations that have been in force. It largely omits national policy papers due to space reasons and because policies may be implemented late, in a changed version, or even be abandoned, not meeting this contribution's title. Bilateral agreements among African states or between African and non-African states (which are basically trade agreements) were also excluded in this analysis, as they are of minor concern for the African citizens.

The use of insects other than food was also not considered here.

Regarding which insect species are edible or not, the list of Jongema [11] was taken as reference. Within the text, law references are marked in italics (sometimes abbreviated) and presented before the ordinary reference list as an Appendix A. Although written differently in the various documents, the abbreviations for "number" were unified according to the corresponding typing conventions, 


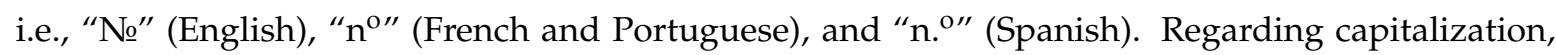
the original version of the acts was retained.

\section{Results}

In Africa, edible insects may be regulated mainly in three different contexts:

- Food law;

- Wildlife resources management;

- Pest management.

The applicability of these regulations will depend fundamentally on whether a definition for a given item ("foodstuff", "wildlife species", etc.) can be extrapolated to edible insects.

\subsection{Food Law}

As in other regions of the world, the food law of a given African country is determined by both international and national regulations. From the international point of view, Codex Alimentarius, AU and the different African trade blocks are the most important ones. As the Codex is well-known, it will be omitted here.

- AU. The African convention on the conservation of nature and natural resources is oriented towards managing the entire African environment, regardless of being farmland or not. Member states are called to "establish, strengthen, and implement specific national standards" (p. 10) for processing respectively production methods and product quality (Article XIII).

- CEMAC. Food security is one of the foci of CEMAC (http://www.cemac.int/node/140). Two institutions are thought to be handling food regulation issues, both localized in Ndjamena, Chad. Access to the homepage of CEBEVIRHA (Commission Économique du Bétail, de la Viande et des Ressources Halieutiques, Economic Commission for Livestock, Meat, and Fishery Resources), was not granted by the authors' internet due to safety concerns. Pôle Régional de Recherche Appliquée au Développement des Systèmes Agricoles d'Afrique Centrale (Regional Growth Market of Applied Research for the Development of Agricultural Systems of Central Africa, PRASAC) is the other authority, conceived as a network for agricultural research regarding the savannah. No documents could be downloaded.

- CEPGL. No food-related documents could be encountered on the union's webpage (http://www.cepgl.org/).

- COMESA. Chapter 18 of the COMESA treaty refers to the "co-operation in agriculture and rural development" (COMESA, 2009, p. 69), aiming towards "common agricultural policy", "regional food sufficiency", productivity increases, and "replacement of imports on a regional basis" (ibid.). In terms of food safety, member states are requested to harmonize their regulation and standards in order to facilitate trade within COMESA borders and cooperate among each other with regard to research incl. that to increase productivity. An early warning system regarding food hazards is also an issue. No more specific documents could be found.

- CEN-SAD. The web presence (https://web.archive.org/web/20080709020642/http://www.uneca. org/cen-sad/reportofthe 6th ordinarysessionoftheEC.htm) of this trade block mentions that during the 2001 meeting in Ouagadougou, Burkina Faso, opinions regarding food security (cave, not food safety) were exchanged. No more details were available.

- EAC. This East African REC issued the EAC food security action plan (2011-2015). ECOWAS In it, they include a FAO definition of 'food security', i.e., "Food security exists when all people, at all times, have physical, social and economic access to sufficient, safe and nutritious food to meet their dietary needs and food preferences for an active and healthy life" (p. 4). In this way, food security also includes food safety. Apart from improving production, quality, and distribution of common foodstuffs, using an alternative food supply of agricultural, aquatic, and forestry systems is one of 
the priority areas of this action plan. This would, in fact, include insects, regardless of whether they are caught from the wild or farmed.

- ECCAS. Like EAC, ECCAS member states agreed to cooperate in terms of agriculture and food supply. Chapter VII of the corresponding treaty (Treaty establishing the Economic Community of Central African States) contains these intentions. As other trade blocks, food supply is supposed to be originated from agriculture and livestock, aquaculture, and forestry management, so insects are potentially included.

- ECOWAS. Article 22 of the ECOWAS treaty (Revised treaty) foresees the establishment of a technical commission for food and agriculture. The corresponding section of cooperation in the food sector is Chapter IV. As in other documents, the focus lies on food security rather than food safety.

- GAFTA. Of this trade union, only the declaration text G قرار الدجلس الاقتصادبإعلان منطقة التجارة الحرة العربية was available. It focuses on the trading conditions of Arab products claiming that a certificate of origin is mandatory, but that imported GAFTA goods will be treated as local ones throughout the member states. It may be assumed that this also includes foodstuffs, but this product was not mentioned in this document.

- IOC. Like other transnational organizations, food security is one of the primary goals of IOC. Comparable to IGAD, the provided IOC documentation [12] focuses on specific projects to improve food security. However, no legal documents could be encountered.

- IGAD. Food security and food safety are primary targets of IGAD, being part in several policy statements and programs published (Regional Strategy, Volume $1 \& 2$ ) rather than concise legal bases.

- MRU. Due to technical reasons, the organization's homepage could not be accessed.

- SACU. Founded in 1910, SACU is the oldest customs union of the world. It recognizes the predominance of the agricultural sector, which plays an important, but variable role in the member states [13]. However, no specific documents could be encountered.

- SADC. In its declaration of agriculture-related actions to take (Dar-es-Salam declaration on agriculture and food security in the SADC region), only aquaculture and "short cycle stocks" (sic!; poultry, small ruminants, pigs) are mentioned. In fact, many insects would be short-cycle livestock. In view of the time of publication, which was far before the FAO started to promote edible insects, opening this definition to productive insects may be an option to be considered, moreover as some insect products like mopane worms (Gonimbrasia belina) are an important product with transregional trading relevance. However, the protocol on wildlife management (Protocol on wildife conservation and law enforcement) does include all animal and plant species and allows a sustainable use of this wildlife, particularly by local communities. However, no specific rules were laid down. The guidelines for the regulation of food safety in SADC states (Regional guidelines for the regulation of food safety in $S A D C$ member states) contain a comprehensive description on how the national food law should be in the 15 member states. Although it does not mention insects as such, the definition of food (" ... any substance [ ... ] intentionally incorporated into the food ... " with a list of duly prohibited substances) would support the inclusion of insects. Many aspects of this document remind on the EU food law, particularly REC (EC) 178/2002, but as that latter, no specific data on the different food types or the evaluation criteria is provided.

- UEMOA. Unlike other trade organizations, UEMOA published a concise regulation of food security and safety. Considering that according to Réglement 007/2007/CM/UEMOA, every animal species can be a foodstuff, insects are potentially included. Chapter II deals with the health monitoring of animals and products made thereof. While Section 1 sets the obligations of the involved actors, Section 2 refers to animal health control and inspection, and Section 3 to animal and animal product movements inside and outside member countries. Chapter III attends food safety with a similar layout (Section 1: obligations, Section 2: control and inspection, and Section 3: product movements). In terms of food safety, Article 84 is particularly interesting since it prohibits the production and the placing on the market of foodstuffs that are hazardous to human and 
animal health, do not respond to the consumer information requirements, do not fulfill the ethics of the international food trade as established by the Codex Alimentarius, or do not cope with the requirements for novel foodstuffs. The latter refers to foodstuffs unknown to the member states' population and consumed marginally and also includes GMOs. Furthermore, the regulation refers to the so-called Secrétariat Régional de la Normalisation, de la Certification et de la Promotion de la Qualité (NORMCERQ) that is in charge of harmonizing the corresponding regulations, but no hint of this activity regarding food could be encountered.

- UMA. The Arab Maghreb Union has a commission for food safety, which, according to its website, met 2007 in Nouakchott, Mauretania. It has ratified several conventions regarding the exchange and quarantine of agricultural products among member countries. However, these documents are not online.

As can be seen, most of these international organizations do not set a concise legal framework for the member states. This is a difference to other trade blocks, e.g., the EU. Instead, policies are proposed. Policy documents are typically placed on consulted ministries' homepages, dealing with ways to increase food security, food safety, intermember states exchange, and food and production-related research. In some cases, policy statements are presented rather than concrete legal frameworks.

Policies seldom address edible insects directly. Some exceptions will be presented on a national level.

On a this level, no data on the food law in Chad and Lesotho could be encountered. Technical and safety reasons made it impossible to access the corresponding web presences in Botswana, Cameroon, Sierra Leone, Sudan, Tanzania, and Togo. FAOLEX was used whenever possible.

No country has explicitly included edible insects in their current food legislation so far. However, direct contact to authorities and consulting the internet provided the following results:

- According to the consulted authorities, edible insects are tolerated in Algeria, Benin, Burkina Faso, Burundi, Cameroon, Central African Republic, Madagascar, Morocco, Namibia, South Africa, Togo, and Tunisia. All these countries lack a specific regulation for edible insects.

- In Congo-Kinshasa, Guinea, and Niger, entomophagy is also tolerated, but during the interviews, an interest in establishing a corresponding legal framework was expressed.

- Benin. The central laboratory for food safety (http://www.lcssa-benin.org/index.php/resultatsanalyses/) offers a series of chemical, microbiological and contaminant-related analyses for all foodstuffs. By extension, this would theoretically also include edible insects.

- Cape Verde. In Lei $n^{o}$ 30/VIIL/2013, "animal" is defined as either a mammal, bird, or bee (Art. 3). From that, "products of animal origin meant for human consumption" derive. In this way, other insects are excluded, making edible insects illegal on the archipelago. The only exception would be bee brood.

- Comoros. Food safety is addressed in the public health code (Code de la santé publique et de l'action sociale pour le bien être de la population), providing a definition for food hygiene, but not for food.

- Gabon. Most food legislation is about fishery products.

- Gambia. The FSQA homepage has a section for regulations, but instead of providing the original texts, bullet points to specific issues are presented of which none applies to edible insects. Within the subsection "standards", a Food Safety and Quality Act from 2011 is mentioned, but could not be found neither on the FSQA nor the FAOLEX pages.

- Ghana. The FDA homepage contains a large set of regulations and codes for many sectors of food policy, and there is a list of different foodstuffs and the parameters they should be analyzed for (https://fdaghana.gov.gh/index.php/certificate-of-analysis/), yet omitting the threshold values. None refers to edible insects.

- Guinea. In fact, most regulation concerns fishery products.

- Madagascar. On 901 pages, MAEP has merged all relevant regulations pertaining agriculture, animal breeding, and fishery into one document. There is no specific Malagasy legislation for 
edible insects, but they are accepted, and the Codex Alimentarius is used when determining the hygiene and edibility of insects. However, Codex specifications apply to foodstuffs in general or to specific, non-insect foodstuffs.

- Malawi. A national policy that promotes insect consumption is said to exist, but could not be retrieved on the internet.

- Mozambique. While there is an extensive regulatory framework for fishery products, a general food act could not be encountered.

- Namibia. A new policy for food safety [14] does mention edible insects specifically, postulating that the Ministry of Agriculture, Water, and Forestry should be responsible to elaborate standards for a series of foodstuffs including insects. This policy was submitted to the cabinet by the Minister of Agriculture, Water, and Forestry, but has not been amended yet.

These results show that edible insects are tolerated in many countries, and although there is no regulation for them at the moment, some governments are interested in developing them.

When working with legal texts, it is important to check the definitions provided there. In the case of the definitions for 'foodstuff', all countries would permit considering insects as such (Table 4), at least in the case of the countries for which such a definition could be encountered. In most cases in which countries apparently lack a foodstuff definition, however, they do have food legislation, but either they work without the preliminary definition or address specific foodstuffs, e.g., meat, fishery products, or eggs. For UEMOA member states, the food definition provided there would have an official character, even in the countries apparently without their own definition, i.e., Burkina Faso and Senegal. Another probable reason for information gaps may the fact that some regulations have simply not been published on the internet. To give an example, a central regulation for food in Togo is the Arrêté interministériel $n^{0} 06 / 08 / M A E P / M E F$. It is mentioned in secondary literature (e.g., [15]) but could not be traced back in the net.

Table 4. Definitions of "foodstuff" in African food regulation frameworks; for Botswana, Burundi, Cameroon, Chad, Comoros, Congo-Brazzaville, Congo-Kinshasa, Djibouti, Equatorial Guinea, Eritrea, Gabon, Gambia, Guinea, Lesotho, Malawi, Mauritania, Libya, São Tomé and Príncipe, South Sudan, and Togo, no definitions could be encountered.

\begin{tabular}{|c|c|}
\hline Country & Definition (Regulation) \\
\hline Algeria & $\begin{array}{l}\text { "... any treated, partially processed or raw substances intended for human consumption and } \\
\text { including beverages, chewing gum and any substances used in the manufacture, preparation } \\
\text { and processing of foods, excluding those used only in the form of drugs or cosmetics." } \\
\left.\text { (Décret exécutif } n^{\circ} 91-53, \text { Art. } 2\right)\end{array}$ \\
\hline Angola & $\begin{array}{l}\text { "... any substance or mixture of substances, in the solid, liquid, pasty or any other suitable } \\
\text { form, intended to provide the human body with the normal elements essential for its } \\
\text { formation, maintenance, and development." (Decreto Presidencial } n^{\circ} 179 / 18, \text { Art. } 4 \mathrm{c} \text { ) }\end{array}$ \\
\hline Benin & $\begin{array}{l}\text { "... any treated, partially processed or raw material intended for human consumption and } \\
\text { includes beverages, chewing gum and all substances used in the manufacture, preparation and } \\
\text { processing of foods, excluding those used only in the form of drugs or cosmetics." } \\
\left(\text { Loi } n^{\circ} 84-009 \text { du } 15 \text { mars } 1984 \text {, Art. 2) }\right.\end{array}$ \\
\hline Botswana & $\begin{array}{l}\text { "... means any animal product, fish, fruit, vegetable, condiment, beverage and any other } \\
\text { substance whatever, in any form, state or stage of preparation which is intended or ordinarily } \\
\text { used for human consumption, and includes any article produced, manufactured, sold or } \\
\text { presented for use as food or drink for human consumption, including chewing gum, and any } \\
\text { ingredient of such food, drink or chewing gum" (Food Control Act, 2) }\end{array}$ \\
\hline Burkina Faso & $\begin{array}{l}\text { "... any treated, partially treated or unwrought substance intended for human consumption, } \\
\text { and includes beverages, chewing gum and all substances used in the manufacture, preparation } \\
\text { and processing of foods, excluding substances used only in form of drugs, cosmetics or } \\
\left.\text { tobacco" (Règlement } n^{\circ} 007 / 2007 / C M / U E M O A, 1\right)\end{array}$ \\
\hline
\end{tabular}


Table 4. Cont.

\begin{tabular}{|c|c|}
\hline Country & Definition (Regulation) \\
\hline Cape Verde & $\begin{array}{l}\text { "... any substance or product, processed or partially processed or unprocessed, intended to be } \\
\text { ingested by, or reasonably likely to be, human beings" (Decreito-Legislativo } n^{\circ} 3 / 2009 \text {, Art. 3.1) }\end{array}$ \\
\hline Central African Republic & $\begin{array}{l}\text { “... any raw or partially processed substance intended for human consumption" } \\
\left(\text { Loi } n^{\circ} 03.04 \text {, Art. 24) }\right.\end{array}$ \\
\hline Egypt & $\begin{array}{l}\text { "... any product or substance intended for human consumption, whether primary, raw, } \\
\text { semi-processed, wholly/partially processed or not processed, including beverages and bottled } \\
\text { water or food additives and any substance including water and gum, except for fodder and } \\
\text { plants and crops before harvest, live animals and birds prior to their transport to } \\
\text { slaughterhouses, sea creatures and farm-raised fish prior to fishing, pharmaceutical products } \\
\text { and cosmetics" (Law } 1 / 2007,(1) / 6)\end{array}$ \\
\hline Eswatini & $\begin{array}{l}\text { "... means food of animal origin including meat, milk, fish, honey and their products. } \\
\text { (Veterinary Public Health Act, Art. 2) }\end{array}$ \\
\hline Ethiopia & $\begin{array}{l}\text { "... means any raw, semi-processed or processed substance for commercial purpose or to be } \\
\text { served for the public in any way intended for human consumption that includes water and } \\
\text { other drinks, chewing gum, supplementary food and any substance which has been used in } \\
\text { the manufacture, preparation or treatment of food, but does not include tobacco and } \\
\text { substances used only as medicines" (Proclamation № 661/2009, Art. } 2,1 / \text { ) }\end{array}$ \\
\hline Ghana & $\begin{array}{l}\text { "... includes water, a food product, a live animal or a live plant, and (a) a substance or a thing } \\
\text { of a kind used, capable of being used or represented as being for use, for human or animal } \\
\text { consumption whether it is live, raw, prepared or partly prepared, (b) a substance or a thing of a } \\
\text { kind used, capable of being used or represented as being for use, as an ingredient or additive } \\
\text { in a substance or a thing referred to in paragraph (a), (c) a substance used in preparing a } \\
\text { substance or a thing referred to in paragraph (a), (d) chewing gum or an ingredient or additive } \\
\text { in chewing gum or a substance used in preparing chewing gum, and (e) a substance or a thing } \\
\text { declared by the Minister to be a food under Section } 146(3) " * \text { (Public Health Act, 2012, Art. 149) }\end{array}$ \\
\hline Guinea-Bissau & $\begin{array}{l}\text { "... any substance, whether or not treated, intended for human consumption, by swallowing } \\
\text { beverages and products of the type of chewing gum, as well as the ingredients used in its } \\
\text { manufacture, preparation and treatment" (Decreto } n^{\circ} 62-E / 92 \text {, Art. 2) }\end{array}$ \\
\hline Ivory Coast & $\begin{array}{l}\text { "... any food, product, or drink intended for human consumption." } \\
\text { (Décret } n^{\circ} 92-487 \text { du } 26 \text { aôut 1992, Art. 2) }\end{array}$ \\
\hline Kenya & $\begin{array}{l}\text { "... includes any article manufactured, sold or represented for use as food or drink for human } \\
\text { consumption, chewing gum, and any ingredient of such food, drink or chewing gum" } \\
\text { (Food, Drugs and Chemical Substances Act, 2.) }\end{array}$ \\
\hline Liberia & $\begin{array}{l}\text { "... articles including liquids used as nutriment for human consumption or use, alcoholic and } \\
\text { nonalcoholic beverages, chewing gum, ice and articles used for components of any such article. } \\
\text { (Public Health Law-Title 33-Liberian Code of Laws Revised, } \S 26.1 \text { ) }\end{array}$ \\
\hline Madagascar & $\begin{array}{l}\text { "... any substance or product, processed, partially processed or unprocessed, intended to be } \\
\text { ingested or reasonably likely to be ingested by humans. This term also includes beverages, } \\
\text { chewing gums and any substance, including water, intentionally incorporated into food } \\
\text { during their manufacture, preparation or processing." (Loi } n^{\circ} 2017-048, \text { Art. 2) }\end{array}$ \\
\hline Mali & $\begin{array}{l}\text { "... any totally processed, partially treated or raw material intended for human consumption } \\
\text { and including beverages, chewing gum and all substances used in the manufacture, } \\
\text { preparation and processing of foods, excluding cosmetics or tobacco or substances used solely } \\
\left.\text { as medicaments" (Décret } n^{0} 06-259 / P-R M d u 3 \text { juin } 2006,2\right)\end{array}$ \\
\hline Mauritius & $\begin{array}{l}\text { "... (a) means any article or substance meant for human consumption and includes (i) drinks } \\
\text { and bottled water; (ii) chewing gum and other products of similar nature and use; and (iii) } \\
\text { articles and substances used or intended for use as ingredients in the composition or } \\
\text { preparation of food; (b) does not include (i) live animals, birds or live fish which are not used } \\
\text { for human consumption while they are alive; (ii) fodder or feeding stuffs for animals, birds or } \\
\text { fish; (iii) drugs or medicine as defined in the Pharmacy Act; and (iv) hormonal products or } \\
\text { veterinary products for use in livestock feed" (Food Act 1998, 2.) }\end{array}$ \\
\hline Morocco & $\begin{array}{l}\text { "... any plant or animal product, raw or wholly or partly processed, intended for human } \\
\text { consumption including beverages, gum and all products that have been used for the } \\
\text { production and preparation or processing of food. This term does not cover plants before } \\
\text { harvest and live animals, with the exception of those prepared for human consumption, as they } \\
\text { are, such as shellfish, and do not cover medicines, cosmetics and tobacco" (Loi } n^{\circ} 28-7 \text {, Art. 2.1) }\end{array}$ \\
\hline
\end{tabular}


Table 4. Cont.

\begin{tabular}{|c|c|}
\hline Country & Definition (Regulation) \\
\hline Mozambique & $\begin{array}{l}\text { "... any substance which is consumed in the natural state, semi-prepared or processed, } \\
\text { intended for human consumption, including beverages, chewing gum and any other substance } \\
\text { used in their manufacture, preparation or treatment. Cosmetics, tobacco and substances used } \\
\text { solely as medicine are excluded." (Decreto } n^{\circ} 15 / 2006 \text { de } 22 \text { de Juhno, Art. } 1 \mathrm{~g} \text { )) }\end{array}$ \\
\hline Namibia & $\begin{array}{l}\text { "... means any article or substance (except a medicine as defined in the Medicines and } \\
\text { Related Substances Control Act, } 1965 \text { [Act } 101 \text { of } 1965] \text { ) ordinarily eaten or drunk by man, } \\
\text { or purporting to be suitable, or manufactured or sold, for human consumption, and includes } \\
\text { any part or ingredient of any such article or substance, or any substance used or intended or } \\
\text { destined to be used as a part or ingredient of any such article or substance" } \\
\text { (Foodstuffs, Cosmetics and Disinfectants Ordinance } 18 \text { of } 1979,1 \text { ) }\end{array}$ \\
\hline Niger & $\begin{array}{l}\text { "... treated, partially treated or unprocessed substance intended for human consumption and } \\
\text { including beverages, chewing gums and all substances used in the manufacture, preparation } \\
\text { and processing of foods excluding substances used solely in the form of medicines, cosmetics } \\
\text { or tobacco" (Décret } n^{\circ} 2011-616 / P R N / M E L, \text { Art. } 7 / 3 \text { ) }\end{array}$ \\
\hline Nigeria & $\begin{array}{l}\text { "... includes any article manufactured, processed, packaged, sold or advertised for use as } \\
\text { food or drink for human consumption, chewing gum and any ingredient which may be mixed } \\
\text { with food for any purpose whatsoever and excludes (a) live animals, birds or fish; (b) articles } \\
\text { or substances used as drugs" (Food and Drugs (Amendment) Decree 1999, 7) }\end{array}$ \\
\hline Rwanda & $\begin{array}{l}\text { "... any items other than pharmaceutical products, cosmetics and tobacco used as food or } \\
\text { drink for human beings and include any substance used in the manufacture or treatment of } \\
\text { food" (Itegeko } n^{\circ} 47 / 2012 \text { ryo kuwa 14/01/2013, Art. 2) }\end{array}$ \\
\hline Senegal & $\begin{array}{l}\text { "... any treated, partially treated or unwrought substance intended for human consumption, } \\
\text { and includes beverages, chewing gum and all substances used in the manufacture, preparation } \\
\text { and processing of foods, excluding substances used only in form of drugs, cosmetics or } \\
\left.\text { tobacco" (Règlement } n^{\circ} 007 / 2007 / C M / U E M O A, 1\right)\end{array}$ \\
\hline Seychelles & $\begin{array}{l}\text { "... means any substance, whether processed, semi-processed or raw, which is prepared, sold, } \\
\text { represented or intended for human consumption, and includes drinks, bottled and packaged } \\
\text { water, chewing gum, other products of similar nature or use and any article, substance or } \\
\text { ingredients used in the composition, manufacture, preparation or treatment of food but does } \\
\text { not include (a) cosmetics; (b) tobacco; (c) plants prior to harvesting; (d) live animals, birds or } \\
\text { live fish which are not used for human consumption while they are alive, (excluding shellfish), } \\
\text { unless they are prepared for placing on the market for human consumption; (e) fodder or feed } \\
\text { for animals, birds or fish; (f) drugs or medicinal products; (g) hormonal products or veterinary } \\
\text { products for use in livestock feed; and (h) residues and contaminants" (Food Act, 2014, Art. 2) }\end{array}$ \\
\hline Sierra Leone & $\begin{array}{l}\text { "... means any article used as food or drink for human consumption, other than drugs or } \\
\text { water, and includes (a) any article which is intended for use in the composition or preparation } \\
\text { of food; and (b) any flavouring matter or condiment and (c) any colouring matter intended for } \\
\text { use in food" (Act №23, 2) }\end{array}$ \\
\hline Somalia & $\begin{array}{l}\text { “... animal products such as meat, milk, eggs, honey, oil, bones, skin, etc" ** } \\
\text { (Veterinary Law Code, Section } 1 \text { ) }\end{array}$ \\
\hline South Africa & $\begin{array}{l}\text { “... any article or substance (except a medicine defined in Medicine and Related Substances } \\
\text { Act (Act } 101 \text { of 1965)) ordinarily eaten or drunk by a person or purporting to be suitable, or } \\
\text { manufactured or sold, for human consumption, and includes any part or ingredient of any } \\
\text { such article or substance, or any substance used or intended or destined to be used as a part or } \\
\text { ingredient of any such article or substance" (Foodstuffs, Cosmetic, and Disinfectants Act №54 of } \\
1972,1 \text { ) }\end{array}$ \\
\hline Sudan & 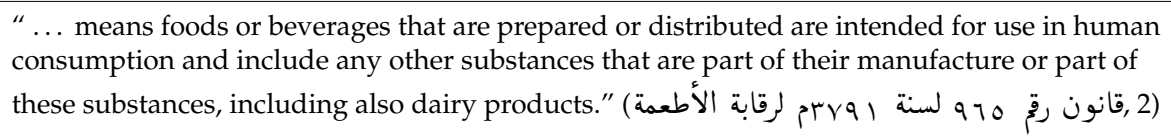 \\
\hline Tanzania & $\begin{array}{l}\text { "... means any article other than drugs, cosmetics and tobacco used as food or drink for } \\
\text { human consumption and includes any substance used in manufacture or treatment of food" } \\
\text { (The Tanzania Food, Drugs, and Cosmetics Act, Art. 3) }\end{array}$ \\
\hline Tunisia & 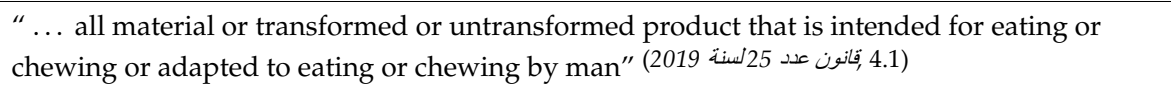 \\
\hline Uganda & $\begin{array}{l}\text { "... includes drink, chewing gum and other products of a like nature and use, and articles } \\
\text { and substances used as ingredients in the preparation of food or drink or of such products, } \\
\text { but does not include (i) water, live animals or birds; (ii) fodder or feeding stuffs for animals, } \\
\text { birds or fish; or (iii) articles or substances used only as drugs" (The Food and Drugs Act, 1) }\end{array}$ \\
\hline
\end{tabular}


Table 4. Cont.

\begin{tabular}{|c|c|}
\hline Country & Definition (Regulation) \\
\hline Zambia & $\begin{array}{l}\text { "... includes any article manufactured, sold or represented for use as food or drink for human } \\
\text { consumption, chewing gum, and any ingredient of such food, drink or chewing gum" } \\
\text { (The Food and Drugs Act, 2) }\end{array}$ \\
\hline Zimbabwe & $\begin{array}{l}\text { "... means any substance which is, in whole or in part, intended for human consumption or } \\
\text { which is intended for entry into, or to be used in the manufacture of, any such substance" } \\
\text { (Food and Food Standards Act, 3) }\end{array}$ \\
\hline
\end{tabular}

* This part must have been amended since it is no longer part of this Act, ${ }^{* *}$ definition of 'animal product'.

Although these definitions basically include edible insects, a further insertion into food law is not possible. This is due to the fact that food inspection framework usually includes a definition of the food category, e.g., 'meat', 'fishery product', etc. With insects being foodstuffs of animal origin, the term 'animal' is defined, if at all, in terms of livestock and species obtained via fishing, sometimes including game species. Interestingly, some regulations seem to make a difference between "animal", "bird", and "fish", suggesting that "animal" as a food provider is perceived as a mammal. In fact, The Food and Drug Act (Art. 1) from Uganda excludes birds and fish from its 'animal' definition. In any case, these definitions usually exclude invertebrates. Some, however, mention honeybees, e.g., Lei $n^{0}$ 30/VIII/2013 of Cape Verde. One of the relatively few countries that actually mentions insects in the animal definition is the Food Act, 2014, of the Seychelles (Art. 2). The Veterinary Law Code of Somalia (Section 1) does not contain an overall definition of foodstuff, but for 'animal product', an 'animal' being "any vertebrate or invertebrate animal other than the human being".

Some nations also have addressed the idea of novel foodstuffs. To provide an example, Niger's Décret $n^{0}$ 2011-616/PRN/MEL defines them as "products or foodstuffs for which human consumption in Niger has so far been unknown or marginal, as well as foods and ingredients made from genetically modified organisms" (Art. 7/2). A definition for novel foodstuffs is also provided by 007/2007/CM/UEMOA. It may be debated, however, if edible insects actually are a novel food in African countries, particularly if marginal consumption is used as a criterion. However, as can be seen in Table 3, the amount of edible insect species varies from country to country, as will the extent of traditional entomophagy. In this way, the issue of insects as novel food will have to be answered on the nation level, also for those cases in which edible insects are traded from one country to another.

\subsection{Wildlife Resources Management}

Africa is known worldwide for its spectacular wildlife, which has been exploited for centuries as game, providing meat and trophies. Fearing the extinction of these valuable resources, most countries have developed a comprehensive regulatory framework to manage these species. Laws pertaining wildlife were issued in order to regulate the usage of the large African animals, particularly mammals, birds, and reptiles such as crocodiles, be it as a trophy obtained via sports hunting, be it as a foodstuff during regular hunting. Hunting legislation basically refers to the species that can be hunted, the methods permitted, and the fee to be paid for the right to hunt under a combination of the aforementioned parameters. Inclusion of arthropods such as insects and arachnids must be seen as incidental and a consequence of the definition for 'animal', particularly if regulations date from the previous century.

Then, and in view of the many other natural resources, it became necessary to regulate the management of, e.g., wood or mineral resources, i.e., activities that compromise the integrity of certain areas. Finally, natural reserves attract tourism, and so, regulation of these also became necessary.

AU has issued the African convention on the conservation of nature and natural resources. It addresses the need of balancing environment protection with sustainable use of the natural resources. In Article V, some basic terms are defined, e.g., "natural resource", "species", "specimen" (which refers to any non-human life-form, dead or alive), "product" (any part or derivative of a specimen), and a series of conservation areas types are recognized (defined more precisely in Annex 2). Among others, Article 
XIV addresses the sustainable use of these resources and Article XVII the traditional rights of local ethnics to make use of them. In Article VI on land and soil, the term "sustainable farming and forestry practices" is coined and considered a goal to follow. Managing these specimens is the basic objective in terms of species diversity (Article IX), be it inside conservation areas, be it outside of them. In the latter case, harvestable populations are allowed. Among other objectives, the introduction of non-native species is to be controlled strictly, and existing populations should be eradicated, pests controlled, and diseases eliminated. This goes along with the phyto-sanitary convention which basically seeks to minimize the impact of, among others, insect pests by restricting the importation of potential sources. Member states are encouraged to regulate the extraction of specimens, avoiding a series of extraction methods specified in Annex 3. Although it may be expected that this passage refers to vertebrates, some of these banned means are used for regular insect hunting, e.g., artificial light sources, target illumination devices, nets (with exceptions as agreed upon by the Conference of the Parties), and traps. It calls the member states to regulate the domestic trade with, transport of, and possession of specimens (Article XI), to ensure the sustainable management of natural resources within development plans (Article XIV), to respect traditional rights and knowledge (e.g., of farmers; Article XVII), enable research (Article XVIII), and promote capacity building and technology transfer (Articles XIX and XX). Still, this paper did not contain concise regulations, but should be seen as a general framework from which other (inter)national regulations may start from.

Below the AU, one of the larger organizations is the Commision des Forêtes d'Afrique Centrale (COMIFAC), which includes Burundi, Cameroun, Central African Republic, Chad, Congo-Brazzaville, Congo-Kinshasa, Gabon, Equatorial Guinea, Rwanda, and São Tomé and Príncipe. In their constituting treaty, they expressed their commitment to support and develop a sustainable use of the forest resources, creating income from these resources (Article 1).

Of all these bases, edible insects only play a minor role, being one of the many forest products that may, or may be not, harvested. The main focus is clearly the game species, either for sport hunting or for bushmeat. Besides, the permitted use of insects (trophy, foodstuff, feedstuff, medicine, etc.) is frequently not stated. In this way, the first approach of asserting the legal status of insects within this area was to determine if insects actually were (respectively could be) included in the 'animal' definitions these regulations provide (Table 5). In some cases (e.g., Burkina Faso), the regulation did contain a concise definition, suggesting that 'animal' was defined using common sense, i.e., a non-human member of the Animalia kingdom. If this is actually the case, then the Décret $n^{0}$ 96-061/PRES/PM/MEE/ MATS/MEFP/MCIA/MTT would in fact be applicable to insects as it refers to "animals".

In other cases, regulations exclude insects. To give an example, Loi $n^{\circ}$ 1/17 du Septembre 2011 portant Commerce de Faune et de Flore Sauvages from Burundi refers, in terms of animals, to a list of mammal, bird, reptile, and plant species.

Table 5. Summary of the references towards edible insects within African wildlife management legislation; numbers refer to the specific article of the regulation in question; for Cape Verde, Namibia, Seychelles, Somalia, South Sudan, and Zambia, regulations' definitions were not applicable to insects; no applicable regulations were found for Libya, São Tomé and Príncipe, Senegal, Sudan, and Zimbabwe.

\begin{tabular}{|c|c|c|c|c|c|c|c|}
\hline Country & Regulation & 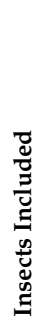 & 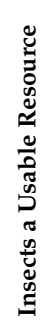 & 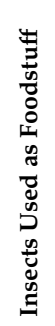 & 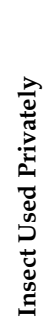 & 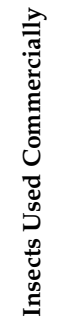 & Additional Information \\
\hline Algeria & Loi $n^{o} 14 / 07$ & 2 & 2 & 2 & 2 & 2 & $\begin{array}{l}\text { permission needed (Art. 5); impact } \\
\text { study requested (Art. 8); payment for } \\
\text { rights }\end{array}$ \\
\hline
\end{tabular}


Table 5. Cont.

\begin{tabular}{|c|c|c|c|c|c|c|c|}
\hline Country & Regulation & 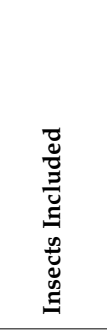 & 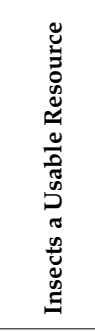 & 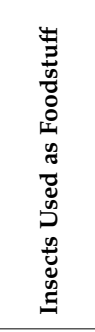 & 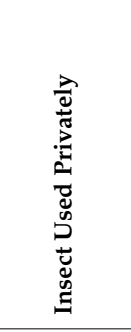 & 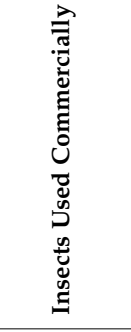 & Additional Information \\
\hline Angola & Lei $n^{o} 6 / 17$ & 4.45 & 4.65 & 12.1 & 65,98 & 4.43 & $\begin{array}{l}\text { Title II: sustainable management of } \\
\text { forests, Title III: that of animals }\end{array}$ \\
\hline Benin & Loi no $2002-16$ & 4 & 36,45 & 96 & 97 & 75,102 & $\begin{array}{l}\text { Art. } 34 \text { states that non-endangered } \\
\text { species still benefit from general } \\
\text { animal protection measures; permit } \\
\text { needed (Art. 73); Chapter III on } \\
\text { wildlife rearing }\end{array}$ \\
\hline \multirow[t]{2}{*}{ Botswana } & $\begin{array}{l}\text { Wildlife Conservation and } \\
\text { National Parks Act }\end{array}$ & 2 & 19 & 19 & 19 & 39 & $\begin{array}{l}\text { Special game licenses for veld produce } \\
\text { gatherers (30); wildlife management } \\
\text { areas (Part III) }\end{array}$ \\
\hline & $\begin{array}{l}\text { Agricultural Resources } \\
\text { Conservation (Utilization } \\
\text { of Veld Products) } \\
\text { Regulations }\end{array}$ & $\mathrm{s}^{*}$ & 2 & 2 & 3 & 4 & $\begin{array}{l}\text { Applies to phane caterpillars } \\
\text { (Gonimbrasia belina) being a } \\
\text { "veld product"; permit if harvest } \\
\text { exceeds } 10 \mathrm{~kg} / \text { person/month }\end{array}$ \\
\hline \multirow[t]{2}{*}{$\begin{array}{l}\text { Burkina } \\
\text { Faso }\end{array}$} & $\begin{array}{l}\text { Décret } n^{0} \text { 96-061/PRES/ } \\
\text { PM/MEE/MATS/ } \\
\text { MEFP/MCIA/MTT }\end{array}$ & $?$ & III & III & 21 & 27,29 & $\begin{array}{l}\text { No definition of "animal" provided; } \\
\text { mammals and birds: permits } \\
\text { depending on the level of catching and } \\
\text { the species }\end{array}$ \\
\hline & Loi $^{\circ}{ }^{\circ} 003-2011 / A N$ & 107 & 115 & 115 & 115 & 115 & $\begin{array}{l}\text { Title III on the wildlife usage incl. } \\
\text { farming }\end{array}$ \\
\hline Burundi & Loi $n^{\circ} 1 / 07$ & $\begin{array}{l}4.25 \\
4.26\end{array}$ & 144 & 144 & 144 & 144 & $\begin{array}{l}\text { Chapter IV, Section } 3 \text { deals with } \\
\text { "non-wood forest products" }\end{array}$ \\
\hline Cameroon & Loi $n^{o}$ 94/01 & 3 & 8 & 8 & 8 & 101 & $\begin{array}{l}\text { Local populations harvesting forest } \\
\text { products for personal use (Art. 8), } \\
\text { permission is needed (Art. 99) }\end{array}$ \\
\hline $\begin{array}{l}\text { Central } \\
\text { African } \\
\text { Republic }\end{array}$ & Loi $n^{0} 08.022$ & 65 & 65 & 65 & 65 & $66-75$ & $\begin{array}{l}\text { Only industrial usage of } \\
\text { "forest products others than wood" } \\
\text { is addressed }\end{array}$ \\
\hline Chad & Loi $n^{0}$ 14/PR/2008 & $\begin{array}{l}\text { I.2, II.2, } \\
\text { III. } 95\end{array}$ & $\begin{array}{l}\text { II. } 2, \\
\text { III. } 141\end{array}$ & III. 76 & $\begin{array}{l}\text { III. } 72-77, \\
\text { III. } 143\end{array}$ & $\begin{array}{l}\text { III. 78-88, } \\
\text { III. } 154, \\
\text { III. } 179\end{array}$ & $\begin{array}{l}\text { Definition of "forest product" is prone } \\
\text { to include insects; Extent of usage } \\
\text { depends on the forest type; traditional } \\
\text { usages is free and does not require a } \\
\text { permit when used for personal needs } \\
\text { (III.76); commercial use is subject to } \\
\text { taxes and can be done by the owners; } \\
\text { special section for ranched fauna } \\
\text { (III. 180-189). }\end{array}$ \\
\hline Comoros & Loi-cadre $n^{0}$ 94-018 & 40 & 40 & 40 & 40 & 40 & $\begin{array}{l}\text { All wildlife usage (41) and } \\
\text { introduction of foreign species (44) } \\
\text { need an official permit }\end{array}$ \\
\hline \multirow[t]{2}{*}{$\begin{array}{l}\text { Congo, } \\
\text { Democratic } \\
\text { Republic } \\
\text { (Kinshasa) }\end{array}$} & Loi no $82-0022$ & 2 & & & & & $\begin{array}{l}\text { "game animals" are part of the term } \\
\text { "fauna", which comprises all } \\
\text { vertebrate and invertebrate species }\end{array}$ \\
\hline & $\begin{array}{l}\text { Arrêté } n^{0} \\
\text { 014/CAB/MIN/ENV/2004 }\end{array}$ & & 33 & & & 38 & $\begin{array}{l}\text { Taxation and basic requirements for } \\
\text { keeping wild animals }\end{array}$ \\
\hline $\begin{array}{l}\text { Congo, } \\
\text { Republic } \\
\text { (Brazzaville) }\end{array}$ & 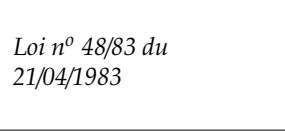 & 2 & & & & & $\begin{array}{l}\text { Insects classified as in no need of } \\
\text { special protection; all hunting requires } \\
\text { a permit (Article 7); law does not refer } \\
\text { to private or commercial uses. }\end{array}$ \\
\hline Djibouti & $\begin{array}{l}\text { Décret } n^{0} \\
\text { 2004-0065/PR/MHUEAT }\end{array}$ & 2 & 2 & 2 & 2 & 2 & $\begin{array}{l}\text { Insects included in "biodiversity"; } \\
\text { no wild animals may be managed. }\end{array}$ \\
\hline Egypt & Law No. 102 of 1983 & 2 & 2 & 2 & 2 & 2 & Applies to protected areas only \\
\hline $\begin{array}{l}\text { Equatorial } \\
\text { Guinea }\end{array}$ & Ley $n .^{\circ} 8 / 1.988$ & 2 & 3 & 3 & 46 & $49-63$ & Permit needed for hunting (Article 9) \\
\hline
\end{tabular}


Table 5. Cont.

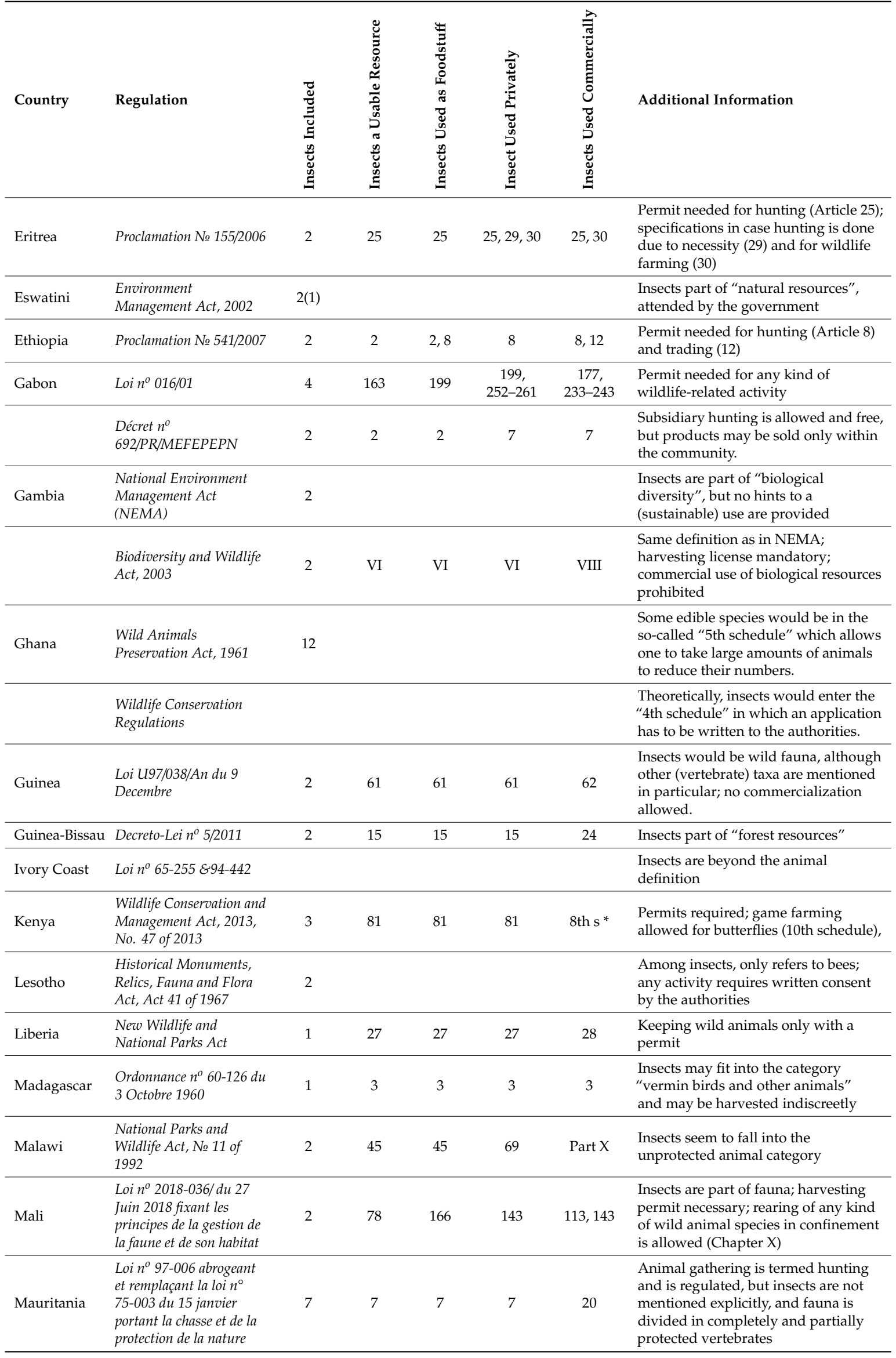


Table 5. Cont.

\begin{tabular}{|c|c|c|c|c|c|c|c|}
\hline Country & Regulation & 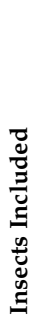 & 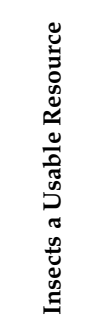 & 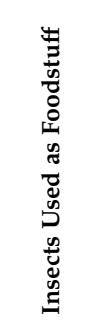 & 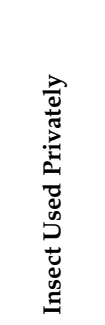 & 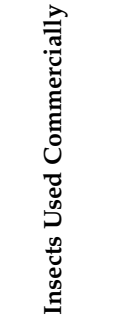 & Additional Information \\
\hline Mauritius & $\begin{array}{l}\text { Native Terrestrial } \\
\text { Biodiversity and National } \\
\text { Parks Act } 2015\end{array}$ & 2 & 26 & 26 & 26 & 26 & $\begin{array}{l}\text { Insect gathering may be seen as a kind } \\
\text { of hunting and thus requires a permit }\end{array}$ \\
\hline Morocco & $\begin{array}{l}\text { Loi } n^{0} 29-05 \text { relative à la } \\
\text { protection des espèces de } \\
\text { flore et de faune sauvages } \\
\text { et au contrôle de leur } \\
\text { commerce }\end{array}$ & 2 & & & & & $\begin{array}{l}\text { Definition in Art. } 2 \text { include insects, } \\
\text { but the hunting regulation refers to } \\
\text { endangered (vertebrate) species only; } \\
\text { other hunting regulations do not refer } \\
\text { to species. }\end{array}$ \\
\hline Mozambique & Lei $n^{\circ} 10 / 99$ & 1 & 20 & 20 & 20 & 23 & Permits are required \\
\hline Niger & $\begin{array}{l}\text { Loi } n^{\circ} \text { 98-07 du } 29 \text { avril } \\
1998 \text { fixant le Régime de } \\
\text { la Chasse et de la } \\
\text { Protection de la Faune }\end{array}$ & 4 & 5 & 5 & 5 & 18 & $\begin{array}{l}\text { Permits requested for hunting and } \\
\text { selling }\end{array}$ \\
\hline \multirow[t]{2}{*}{ Nigeria } & Forest Regulations & 2 & 20 & 20 & 20 & 20 & $\begin{array}{l}\text { Insects are "minor forest produce" } \\
\text { as defined by Art. } 2 \text { Forest Law; } \\
\text { harvesting them requires a permit }\end{array}$ \\
\hline & Wild Animals Law & 2 & 43 & 43 & 43 & & Killing animals in times of famine \\
\hline Rwanda & $\begin{array}{l}\text { Itegeko } n^{0} 70 / 2013 \\
\text { ryokuwa } 07 / 09 / 2013 \\
\text { rigenga urosobe } \\
\text { rw'ibinyabuzima mu } \\
\text { Rwanda }\end{array}$ & 2 & 29 & 29 & 29 & & Using biodiversity requires a permit \\
\hline Tanzania & $\begin{array}{l}\text { Wildlife Conservation Act, } \\
2008\end{array}$ & 3 & 55 & 55 & 55 & 55,89 & $\begin{array}{l}\text { Permits and licenses required for any } \\
\text { wildlife-related activity }\end{array}$ \\
\hline Togo & $\begin{array}{l}\text { Loi } n^{\circ} 2008-09 \text { portant } \\
\text { Code Forestier }\end{array}$ & 2 & Title IV & Title IV & Title IV & $\begin{array}{l}\text { 14, Title } \\
\text { IV }\end{array}$ & $\begin{array}{l}\text { Permits and licenses required for any } \\
\text { wildlife-related activity }\end{array}$ \\
\hline Tunisia & $\begin{array}{l}\text { Loi } n^{\circ} 20 \text { portant Code } \\
\text { forestier }\end{array}$ & 3 & 215 & 215 & 211,215 & & $\begin{array}{l}\text { Animal products from forests may not } \\
\text { be placed on the market }\end{array}$ \\
\hline Uganda & $\begin{array}{l}\text { Uganda Wildlife Statute, } \\
1996\end{array}$ & 2 & Part VI & Part VI & Part VI & $\begin{array}{l}\text { Part VI, } \\
\text { part VII }\end{array}$ & $\begin{array}{l}\text { Permits and licenses required for any } \\
\text { wildlife-related activity }\end{array}$ \\
\hline
\end{tabular}

Wildlife can be managed or protected. In most countries, wildlife protection is mainly focused on large animals, typically hunting species. Some nations, however, also include insects. The Décret $n^{o}$ 2004-0065/PR/MHUEAT of Djibouti puts all national animal species under protection, i.e., also the insects. In Cape Verde, the Decreto-Regulamentar $N^{\circ}$ 7/2002 lists several beetle species as protected, i.e., the scarabids Aphodius spp., the hydrophilids Berosus spp., the buprestid Chrysobothris dorsata, the dytiscid Eretes sticticus, the cerambycids Xystrocera spp., and the tenebrionids Alphitobius laevigatus, Tenebrio spp., and Zophobas spp., which are all edible. So, local consumers have to take care not to feed on these species.

- $\quad$ Cape Verde. No regulation on wildlife management could be found. However, the Decreto-Regulamentar $n^{0} 7 / 2002$ classifies the national fauna into several types, with different levels of protection. It contains a large list of beetles, of which according to [11] some are edible, at least at the genus level. Unless bred in captivity, these species may not be extracted from the wild or managed in any commercial way (Article 9). For the commercial use of endemic species, a permit from the 
government is mandatory. Introducing exotic species (as farming insects would be) can only be done after authorization from the government (Article 13). As mentioned before, the list also includes the classical tenebrionid genera Alphitobius, Tenebrio, and Zophobas. Although the text refers to Tenebrio guineensis, all Tenebrio species are considered edible. The mentioned "Zophobas atratus concolor" is basically Z. atratus. This one and Alphitobius laevigatus are typically used for food. Installing tenebrionid farms on Cape Verde may therefore be a challenge because the introduction of foreign populations, certifying the captivity origin of national populations or catching the initial stock from the wild are all subject to authorization.

- Congo-Democratic. The situation appears unclear. Unlike other nations, "non-wood forestry products" as defined in the forest act (Loi $\left.n^{\circ} 11-2002\right)$ only includes plant products. Wildlife management seems to be regulated by the national hunting law (Loi $n^{\circ}$ 82-0022) and derived acts. Its definition of "game" refers to all vertebrates but amphibians and fish (Article 2) in contrast to "fauna", which includes both vertebrate and invertebrate species. The rest of the law only refers to game hunting issues. However, the Arrêté interministèriel $n^{\circ} 003 / C A B / M I N / E C N-E F / 2006$ and $n^{\circ} 099 / C A B / M I N / F I N A N C E S / 2006$, which fix the financial framework for wildlife usage deals with "fauna" and also includes "cocoons", "nymphs", and "dead insects". They are part of the "sub-product" section of the partially protected animals' tax table. It is suggested that these sub-products refer to ornamental insects sold as dried specimens rather than collecting edible insects for consumption. Still, the implementing regulation Arrêté $n^{0}$ 014/CAB/MIN/ENV/2004 includes specifications for capturing (Article 23) and keeping wild animals (33, 34, and 37-40), i.e., animals in terms of "fauna" and this would include insects. These specifications require regular veterinary controls.

- Djibouti. Not much could be found on wildlife management. Loi $n^{0} 43 / A N / 83 / 1$ re $L$ has prohibited any wildlife management for a period of ten years, this law dating from 1983 . The more recent Décret $n^{0}$ 2004-0065/PR/MHUEAT on biodiversity protection follows this idea, prohibiting any kind of wildlife management.

- Gabon. There is an interesting, publically available legislation on wildlife management. The forest code (Loi $n^{0}$ 016/01) regulates the management of forest resources of which insects are part of. Subject to several permits, the fauna can be used economically and also within traditional frames for basic necessity requirements. Décret $n^{0}$ 18/PR/MEFEPEPN regulates the establishment of wild animal breeding units to produce, among others, foodstuffs (Article 2), while Décret $n^{o}$ 692/PR/MEFEPEPN focuses on the customary usage of forest products. A position paper [16] promotes a sustainable usage of these resources for the coming years.

- Guinea. The Loi U97/038/An has been clearly made for vertebrates and, in particular, game species. However, insects also fit into the "wildlife fauna" definition, and Chapter 9 regulates the use of unprotected species (a concrete list of the protection status is, however, not provided, and including insects in this section is an assumption by the authors), claiming that handling up to five specimens of the given species at a time is allowed, but contacting the local forest inspector is mandatory if this number is exceeded. This would be the case in harvesting edible insects.

Finally, a modern way of handling insects is by farming them. A survey conducted via FAOLEX in search of applicable data did not yield any results.

So, edible insects can be handled in many African countries in a traditional way, but typically after an official permit was provided.

\subsection{Edible Insects in Pest Legislation}

Some pest insects are edible, e.g., mealworms or locusts which, when swarming, are responsible not only for marked economic losses but may also trigger famines. Thus, there are other joint ventures

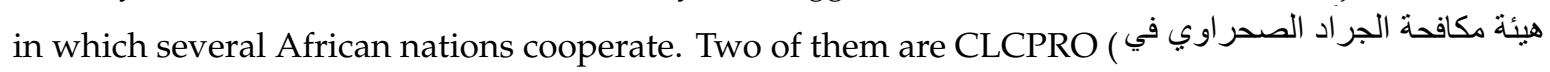
Commission de Lutte contre le Criquet Pèlerin dans la Région Occidentale, 
هيئة مكافحة الجراد ( Commission for Fighting the Desert Locust in the Western Region) and CRC الصحراوي في المنطقة الوسطى (لهission for Controlling the Desert Locust in the Central Region), hosted by FAO. Both commissions are dedicated to preventing damages to crops caused by swarming desert locusts (Schistocerca gregaria). The use of this natural resource as foodstuff has not been contemplated so far, mostly out of the sheer size of locust swarms, and so no regulation in this issue has been established.

Besides, most African nations have more or less detailed pest legislation. There is usually one basic regulation that defines pests in a way that insects are included (Table 6) and provide measures on what to do to ensure pest reduction. In addition, many countries have specific acts dealing with plant diseases and pests in which the corresponding insect species are listed (Tables 7-10). To give an example, Morocco issued an interesting regulation for the control for the African palm weevil (Rhynchophorus ferruguineus). This regulation makes fighting this weevil obligatory, and a Moroccan governorate was classified as a quarantine zone, forbidding all transport of palms out of this area. Palms affected by the weevil must be destroyed (Arrêté conjoint du ministre de l'agriculture et de la pêche maritime et du ministre de l'intérieur $n^{0}$ 287-09 du 30 janvier 2009 édictant des mesures d'urgence destinées à la lutte contre le Charançon rouge du palmier (Rhynchophorus ferrugineus)). However, for the scope of the present contribution, the fact that these species are not permitted is the decisive information rather than the measures taken to control these pest species. In this way, rearing and placing on the market this particular species would be against the law.

Table 6. Pest insect legislation pertaining edible insect species (contained in "all pest insect species"); No data could be obtained for Angola, Djibouti, Equatorial Guinea, Ethiopia, Gabon, Lesotho, Senegal, Sierra Leone, Somalia, South Sudan, Sudan, and Togo.

\begin{tabular}{|c|c|}
\hline Country & Law \\
\hline Algeria & Loi $n^{\circ} 87-17$ \\
\hline Benin & Loi $n^{\circ}$ 91-001, Décret $n^{\circ}$ 92-258 \\
\hline Botswana & Plant Protection Act 2007 \\
\hline Burkina Faso & Loi $n^{o}$ 025-2017/AN \\
\hline Burundi & Décret-loi no $1 / 033$ \\
\hline Cameroon & Loi $n^{o} 2003 / 003$ \\
\hline Cape Verde & Lei $n^{o}$ 29/VIII/2013. \\
\hline Central African Republic & Loi $n^{\circ} 62-350$ \\
\hline Chad & Loi $n^{o}$ 14/PR/95 \\
\hline Comoros & Décret du 24 juin 1903 \\
\hline Congo-Kinshasa & Décret $n^{0} 05 / 162$ \\
\hline Congo-Brazzaville & Loi $n^{\circ} 52-1256$ \\
\hline Egypt & قانون الزراعة رقم 53 لسنة 1966 \\
\hline Eritrea & Plant Quarantine Proclamation \\
\hline Eswatini & Plant Control Act, 1981 \\
\hline Gambia & Plant Importation and Regulation Act. \\
\hline Ghana & Plants and Fertilizer Act, 2010 \\
\hline Guinea & Loi L/92/027/CTRN \\
\hline Guinea-Bissau & Decreto-Lei NQ 4/99 \\
\hline Ivory Coast & Loi $n^{o} 64-490$ \\
\hline Kenya & Plant Protection Act \\
\hline Liberia & Agricultural Law \\
\hline Libya & قانون رقم 27 لسنة 1968 بثأن وقابة النباتات \\
\hline Madagascar & Ordonnance $n^{\circ} 86-013$ \\
\hline Malawi & Plant Protection Act, 1969 \\
\hline Mali & Loi $n^{o}$ 02-013 du 03 juin 2002 \\
\hline Mauritania & Loi $n^{\circ} 2000-042$ \\
\hline Mauritius & Plant Protection Act 2006 \\
\hline
\end{tabular}


Table 6. Cont

\begin{tabular}{ll}
\hline Country & Law \\
\hline Morocco & Dahir du 20 septembre 1927 \\
Mozambique & Decreto $n^{\circ} 5 / 2009$ de 1 de Junho \\
Namibia & Plant Quarantine Act 2008 \\
Niger & Loi $n^{\circ} 2015-35$ du 26 mai 2015 \\
Nigeria & Agriculture (Control of Importation) Act \\
Rwanda & Itegeko $n^{\circ} 16 / 2016$ \\
São Tomé \& Príncipe & Decreto Lei $n^{\circ} 5 / 2016$ \\
Seychelles & Plant Protection Act \\
South Africa & Agricultural Pests Act \\
Tanzania & Plant Protection Act \\
Tunisia & Loi $n^{\circ}$ 92-72 \\
Uganda & Plant Protection and Health Act \\
Zambia & Plant Pests and Diseases Act \\
Zimbabwe & Plant Pests and Diseases Act \\
\hline
\end{tabular}

Swarming locusts have been a threat for the agriculture for millennia. Along with the CLCPRO and CRC initiatives, many countries have adopted national regulations. However, only some do actually include concrete measures. In other countries, the fight against locusts is documented legally by the will to build up corresponding organizations and initiatives, i.e., the national anti-locust agency (ANLA) in the Chadian Loi $n^{0} 005 / P R / 2007$, IFVM in Madagascar (Décret $n^{0} 2017-064 d u 31$ du janvier 2017), the CNLP in Mali (Loi no 06-065 du 29 décembre 2006 and subsequent texts), the PLUCP in Niger (Arrêté $n^{\circ}$ 13/MDA/DPV), and the campaigns in Morocco (Loi n $n^{0}$ 57-02) and Tunisia (Décret $n^{0}$ 88-1751). In those countries, locust may be combatted efficiently, but this is not reflected in the law.

Table 7. Pest insect legislation pertaining edible insect species (as presented in [11]): locusts (Orthoptera; all species are Acrididae, except for Zonocerus variegatus (Zygomorphidae)).

\begin{tabular}{|c|c|c|}
\hline Species & Country & Law \\
\hline \multirow{10}{*}{ Acrididae spp. ("locusts") } & Botswana & Locusts Act \\
\hline & Burundi & Ordonnance $n^{\circ} 53$ \\
\hline & Chad & Loi $n^{\circ}$ 005/PR/2007 \\
\hline & Egypt & قرار وزاري رقم 11 لسنة $197 V$ \\
\hline & Keyna & Plant Protection Rules \\
\hline & Lesotho & Locust Destruction Proclamation \\
\hline & Madagascar & Décret $n^{\circ} 2017-064$ \\
\hline & Mauritania & Décret $n^{o} 2002-062$ du 25 juillet 2002 \\
\hline & Namibia & Regulations relating to the Destroying of Locusts \\
\hline & Sudan & قانون أبادة الجراد لسنة 1907م \\
\hline \multirow{3}{*}{ Anacridium melanorhodon } & Mauritius & Plant Protection Act 2006 \\
\hline & Seychelles & Plant Protection Act \\
\hline & Kenya & Plant Protection Order, Plant Protection Rules \\
\hline \multirow[t]{2}{*}{ Locusta migratoria migratorioides } & Zambia & Plant Pests and Diseases (Pests and Alternate Hosts) Order \\
\hline & Zimbabwe & Locust Control Act [Chapter 19:06]. \\
\hline \multirow{2}{*}{ Locustana pardalina } & Eswatini * & Plant Control Act, 1981 \\
\hline & Zimbabwe & Locust Control Act \\
\hline Melanoplus differentialis & Mauritius & Plant Protection Act 2006 \\
\hline \multirow{4}{*}{ Nomadacris septemfasciata } & Eswatini & Plant Control Act, 1981 \\
\hline & Kenya & Plant Protection Order, Plant Protection Rules \\
\hline & Zambia & Plant Pests and Diseases (Pests and Alternate Hosts) Order \\
\hline & Zimbabwe & Locust Control Act [Chapter 19:06]. \\
\hline \multirow{3}{*}{ Schistocerca gregaria } & Egypt & قرار وزاري رقم V l لسنة VVI 97 بوضع نظام مكافحة الجراد الصحراوي \\
\hline & Kenya & Plant Protection Order, Plant Protection Rules \\
\hline & Zimbabwe & Locust Control Act \\
\hline Zonocerus variegatus & Mozambique & Decreto $n^{0} 5 / 2009$ \\
\hline
\end{tabular}

* termed "Locusta pardelina" in this act. 
Table 8. Pest insect legislation pertaining edible insect species (as presented in [11]: butterflies and moths (Lepidoptera).

\begin{tabular}{|c|c|c|c|}
\hline Family & Species & Country & Law \\
\hline Cossidae & Cossus cossus & Algeria & Décret exécutif $n^{\circ} 95-387$ \\
\hline \multirow{4}{*}{ Crambidae } & \multirow{2}{*}{ Chilo spp. } & Kenya & Plant Protection Order \\
\hline & & Mozambique & Decreto $n^{o} 5 / 2009$ \\
\hline & \multirow[t]{2}{*}{ Ostrinia furnacalis } & \multirow[t]{2}{*}{ Botswana } & Plant Protection Act 2007 \\
\hline & & & Plant Pests and Diseases (Pest Control) \\
\hline \multirow[t]{6}{*}{ Gelechiidae } & Pectinophora gossypiella & Zambia & $\begin{array}{l}\text { Regulations, Plant Pests and Diseases } \\
\text { (Pests and Alternate Hosts) Order }\end{array}$ \\
\hline & Busseola fusca & Kenya & Plant Protection Order \\
\hline & Helicoverpa spp. & Cape Verde & Portaria $n^{\circ} 37 / 2015$ \\
\hline & Heliathis sn & Botswana & Plant Protection Act 2007 \\
\hline & Heltotnts spp. & Seychelles & Plant Protection Act \\
\hline & H. zea & Tunisia & Arrêté du Ministre de l'agriculture du 31 mai 2012 \\
\hline \multirow[t]{6}{*}{ Noctuidae } & & Botswana & Plant Protection Act 2007 \\
\hline & Spodoptera spp. & Mozambique & Decreto $n^{0} 5 / 2009$ \\
\hline & & Tunisia & Arrêté du Ministre de l'agriculture du 31 mai 2012 \\
\hline & & Mozambique & Decreto $n^{0} 5 / 2009$ \\
\hline & S. frugiperda & South Africa & Control Measures Relating to Fall Armyworm \\
\hline & & Tunisia & Arrêté du Ministre de l'agriculture du 31 mai 2012 \\
\hline Pieridae & Pieris spp. & Mozambique & Decreto $n^{0} 5 / 2009$ \\
\hline \multirow{3}{*}{ Pyralidae } & \multirow{2}{*}{ Chilo spp. } & Benin & Arrêté interministériel $n^{\circ} 128$ \\
\hline & & Botswana & Plant Protection Act 2007 \\
\hline & Acherontia styx & Mozambique & Decreto $n^{0} 5 / 2009$ \\
\hline \multirow{3}{*}{ Sphingidae } & Agrius convolvuli & Botswana & Plant Protection Act 2007 \\
\hline & Clanis bilineata & Mozambique & Decreto $n^{0} 5 / 2009$ \\
\hline & Erinnyis ello & Mozambique & Decreto $n^{0} 5 / 2009$ \\
\hline
\end{tabular}

Table 9. Pest insect legislation pertaining edible insect species (as presented in [11]): beetles (Coleoptera); Eswatini also refers to "woodborer beetles", but without any species information, a term that, in fact, can be used to several taxa.

\begin{tabular}{|c|c|c|c|}
\hline Family & Species & Country & Law \\
\hline \multirow{5}{*}{ Ceram-bycidae } & Anoplophora spp. & Tunisia & Arrêté du Ministre de l'agriculture du 31 mai 2012 \\
\hline & A. chinensis & Mauritius & Plant Protection Act 2006 \\
\hline & A. glabripennis & Mauritius & Plant Protection Act 2006 \\
\hline & Monochamus spp. & Tunisia & Arrêté du Ministre de l'agriculture du 31 mai 2012 \\
\hline & Leptinotarsa spp. & Benin & Arrêté interministériel $n^{\circ} 128$ \\
\hline \multirow{6}{*}{ Chryso-melidae } & \multirow{6}{*}{ L. decemlineata } & Malawi & Plant Protection Act, 1969 \\
\hline & & Mauritania & Arrêté no R-0031257 du 12 novembre 2002 \\
\hline & & Mauritius & Plant Protection Act 2006 \\
\hline & & Mozambique & Decreto $n^{0} 5 / 2009$ \\
\hline & & Seychelles & Plant Protection Act \\
\hline & & Tunisia & $\begin{array}{l}\text { Arrêté du Ministre de l'agriculture du } 31 \text { mai } 2012 \\
\text { Plant Pests and Diseases (Pest Control) }\end{array}$ \\
\hline \multirow{14}{*}{ Curculi-onidae } & & Zambia & $\begin{array}{l}\text { Regulations, Plant Pests and Diseases } \\
\text { (Pests and Alternate Hosts) Order }\end{array}$ \\
\hline & Anthonomus spp. & Mozambique & Decreto $n^{o} 5 / 2009$ \\
\hline & \multirow{2}{*}{ Cosmopolites sordidus } & Kenya & Plant Protection Order \\
\hline & & Mauritania & Arrêté no R-0031257 du 12 novembre 2002 \\
\hline & \multirow{3}{*}{ Rhynchophorus spp. } & Benin & Arrêté interministériel $n^{\circ} 128$ \\
\hline & & Mauritania & Arrêté no R-0031257 du 12 novembre 2002 \\
\hline & & Mauritius & Plant Protection Act 2006 \\
\hline & \multirow[t]{2}{*}{ R. ferrugineus } & Morocco & Arrêté conjoint (...) no 287-09 \\
\hline & & Tunisia & Arrêté du Ministre de l'agriculture du 31 mai 2012 \\
\hline & R. phoenicis & Mauritius & Plant Protection Act 2006 \\
\hline & Scyphophorus & Kenya & Plant Protection Order \\
\hline & acupunctatus & Mozambique & Decreto $n^{0} 5 / 2009$ \\
\hline & \multirow{2}{*}{ Sitophilus oryzae } & Kenya & Plant Protection Order \\
\hline & & Zambia & $\begin{array}{l}\text { Plant Pests and Diseases } \\
\text { (Pests and Alternate Hosts) Order }\end{array}$ \\
\hline
\end{tabular}


Table 9. Cont.

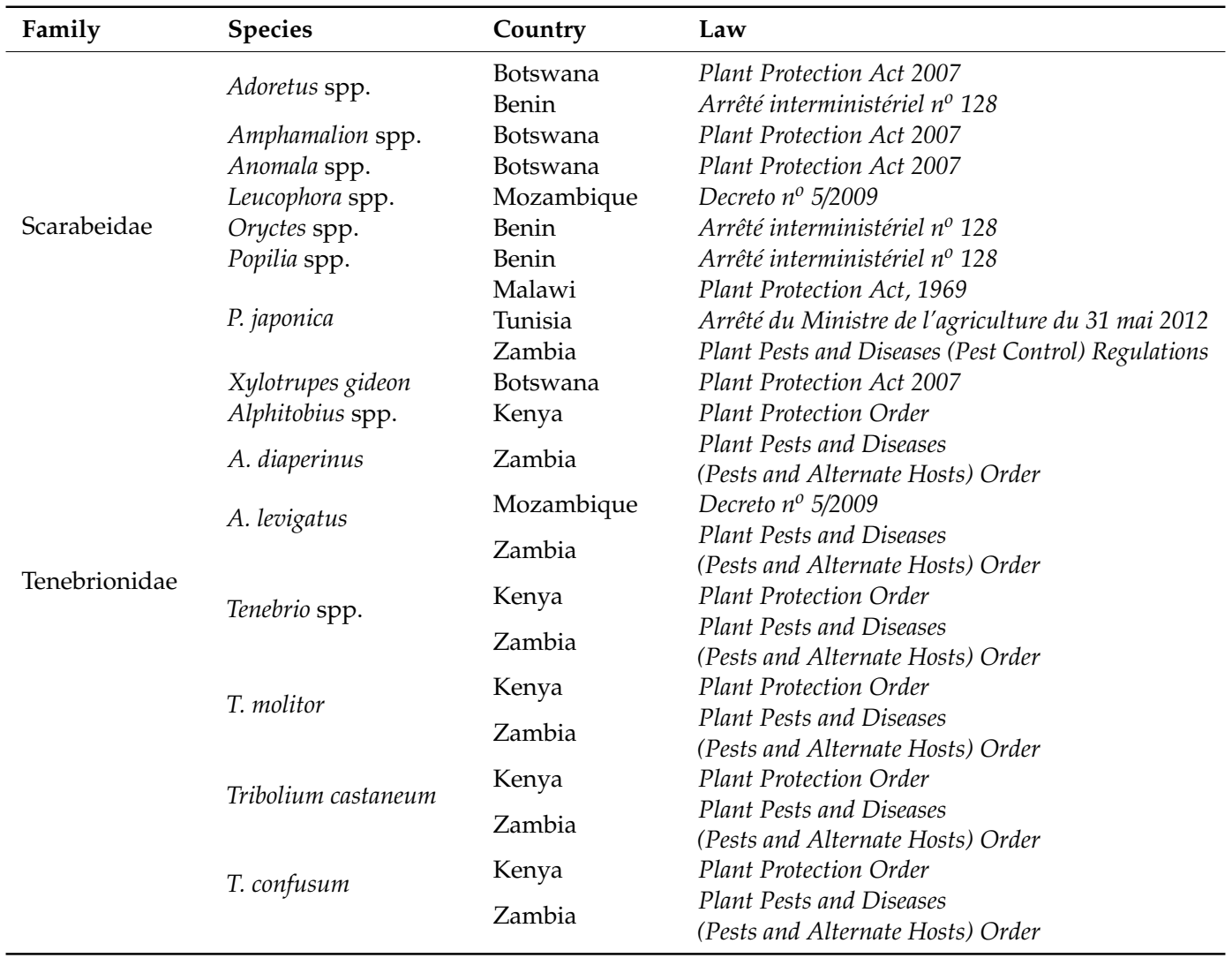

While locusts, butterfly caterpillars, and beetle grubs and larvae are relative well-known food insects, some of the species contained in Table 10 are not, particularly the cockroach and fly species. It should be stressed that the species listed are known to be edible, at least in some parts of their ranges, which may not necessarily be Africa. The record of edibility of Periplaneta americana comes from Brazil, that of Anastrepha ludens from Mexico.

Table 10. Pest insect legislation pertaining edible insect species (as presented in [11]): other orders.

\begin{tabular}{|c|c|c|c|c|}
\hline Order & Family & Species & Country & Law \\
\hline \multirow{3}{*}{ Blattodea } & \multirow{2}{*}{ Blattidae } & Blatta orientalis & Zambia & $\begin{array}{l}\text { Plant Pests and Diseases } \\
\text { (Pests and Alternate Hosts) Order }\end{array}$ \\
\hline & & $\begin{array}{l}\text { Periplaneta } \\
\text { americana }\end{array}$ & Zambia & $\begin{array}{l}\text { Plant Pests and Diseases } \\
\text { (Pests and Alternate Hosts) Order }\end{array}$ \\
\hline & Ectobiidae & Blatella germanica & Zambia & $\begin{array}{l}\text { Plant Pests and Diseases } \\
\text { (Pests and Alternate Hosts) Order }\end{array}$ \\
\hline \multirow{6}{*}{ Diptera } & \multirow{6}{*}{ Tephritidae } & \multirow{3}{*}{ Anastrepha spp. } & Benin & Arrêté interministériel $n^{\circ} 128$ \\
\hline & & & Botswana & Plant Protection Act 2007 \\
\hline & & & Mauritania & $\begin{array}{l}\text { Arrêté } n^{\circ} R-0031257 \text { du } \\
12 \text { novembre } 2002\end{array}$ \\
\hline & & \multirow{3}{*}{ A. ludens } & Mozambique & Decreto $n^{\circ} 5 / 2009$ \\
\hline & & & Mauritius & Plant Protection Act 2006 \\
\hline & & & Tunisia & $\begin{array}{l}\text { Arrêté du Ministre de l'agriculture } \\
\text { du } 31 \text { mai } 2012\end{array}$ \\
\hline \multirow{6}{*}{ Hemiptera } & Tipulidae & Tipula paludosa & Botswana & Plant Protection Act 2007 \\
\hline & \multirow{2}{*}{ Alydidae } & Leptocorisa acuta & Mozambique & Decreto $n^{0} 5 / 2009$ \\
\hline & & L. oratorius & Mozambique & Decreto $n^{0} 5 / 2009$ \\
\hline & Psyllidae & Psylla spp. & Mozambique & Decreto $n^{0} 5 / 2009$ \\
\hline & Pyrrhocoridae & Dysdercus spp. & Botswana & Plant Protection Act 2007 \\
\hline & Tessaratomidae & $\begin{array}{l}\text { Tessaratoma } \\
\text { papillosa }\end{array}$ & Mozambique & Decreto $n^{o} 5 / 2009$ \\
\hline Hymenoptera & Formicidae & Atta cephalotes & Botswana & Plant Protection Act 2007 \\
\hline
\end{tabular}


As a summary of the previous tables, Table 11 provides an overview of the current legal situation of edible in the different African nations.

Table 11. Summary of the legal context of edible insects in Africa.

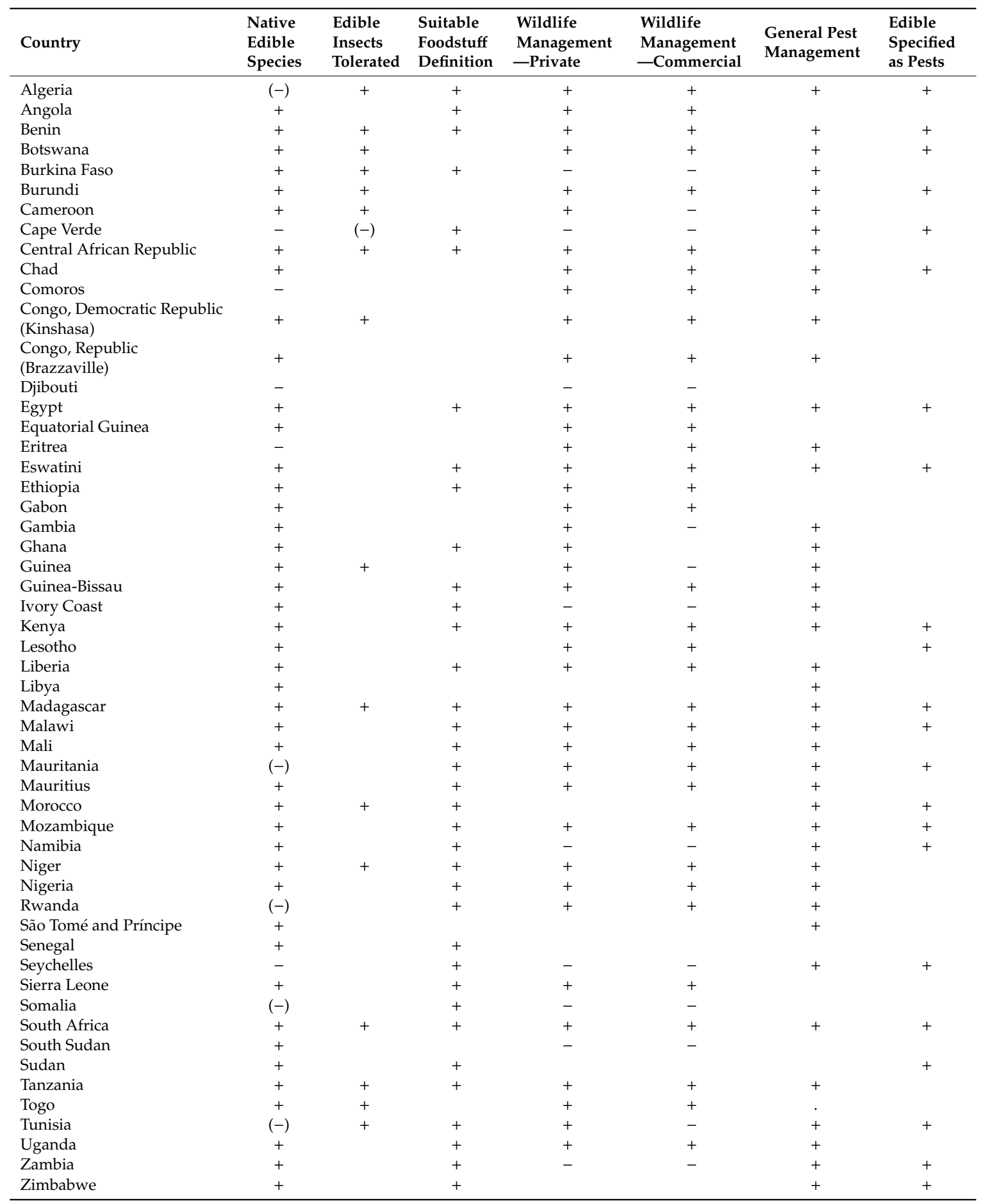

\section{Discussion}

\subsection{Data Availability}

One of the main difficulties in carrying out the present survey was data gathering. Getting first-hand information from the corresponding authorities was challenging. However, as the group of authors comprised African and European scientists, the African colleagues had better chances in 
getting in contact with these authorities. A clear cut was seen between the responses of countries where French and Arabic are spoken (attended by the African colleagues) and those in which English or Portuguese are the official languages (attended by the European colleagues), with the latter responding very late, if at all (despite several attempts made to get an answer), while the African colleagues were able to provide results within two weeks. Differences between the authorities and citizens asking for their advice is a global phenomenon, but also African researchers make special emphasis on the local conditions [17].

Data availability is also an important issue on the internet; some countries did not provide their current legislation on the corresponding government portals. Instead, data had to be traced via other sites, especially FAOLEX. Still, gaps remained, either due to technical or internet safety reasons, or simply because some governments do not put these sources online.

In this context and beyond the current survey, it was noted that most regulatory texts were written either in French, English, or Portuguese, i.e., the administrative languages from colonial times. The only exceptions were the regulations presented (sometimes exclusively) in Arabic of the North African countries, and the full set of regulations from Ethiopia and Rwanda, which were either bilingual (Amharic and English) or even trilingual (Kinyarwanda, English, and French). While this was rather advantageous for the researchers, this may pose a problem for the local African citizens. In Africa, there are more than 2000 languages spoken, and in many countries, the percentage of the population that understands these official languages completely may be relatively low. This, of course, varies strongly among countries, ranging between 35\% (Mali) and 88\% (Eswatini) in 2018 (http://data.uis.unesco.org/Index.aspx?queryid=166\#). So, there is a risk that a certain portion of a country's population may not be able to understand the laws of their own country. However, the situation is changing in some countries. The web presence of the government of South Africa (https://www.gov.za/) has been presenting regulations in several of its eleven official languages, usually English plus another one.

\subsection{Edible Insects in African Food Legislations}

With the exception of phane in Botswana, edible insects have not been considered in the African food law, neither on the national nor on international level. This may be surprising in view of the rich entomophagy tradition that exists in Africa. Van Huis [6] stressed the importance of edible insects in the different regions of the continent, which range from using them in those seasons of the year in which other natural foodstuffs are rarer to the simple reason that insects are consumed because of their taste. This is a completely different scenario from, e.g., the EU where insect-consuming tradition is almost inexistent, and insects are treated as truly novel foods that enter the European food market. In this way, the EU novel food regulation opens this market, and future legal acts will incorporate insects into the public health surveillance, adopting as much as possible from existing regulation, but attending, at the same time, the idiosyncrasies of these foodstuffs, e.g., microbiological criteria. This may be flanked by national European guidelines [7]. However, food law in Africa by itself is the key to this finding.

It should be stressed that, on one hand, African food legislations are merely starting to adapt to the current standards experienced in other parts of the world, and that, on the other hand, the progress in that varies markedly among countries. Some laws cited in the present contribution date down to the 1900s and are still in power. Yet, these are exceptions, and many laws date from the 1990s to the 2010s. In some countries, no food law could be encountered, and if available, many laws seem to lack a concrete depth. In some way, many of these texts express expectations about the issues the address, leaving a very large range for interpretations, making law less transparent. However, this phenomenon is far from being exclusively African. Many EU laws also contain these kinds of expectations, e.g., REG (EC) 178/2002. However, subsequent acts provide the details of the bases set in these general laws, e.g., REG (EC) 2073/2005 on the microbiological criteria for a series of foodstuffs. Still, the current EU novel food regulation (REG (EC) 2015/2283) also sets the bases for novel food certifications, but does not 
contain specific indication on production, processing, or quality control. A corresponding amendment of REG (EC) 2073/2005 for the EU is dearly awaited.

So, African food laws are sometimes outdated and lack depth, which would increase their applicability. However, food safety in Africa is a basic problem, regardless of how efficient the legislation is. Kussaga et al. (2013) [18] present a large list of microbiological and chemical risks detected in African foodstuffs, ranging from pesticides, mycotoxins, heavy metals, over many bacteria to a series of vermiform parasites. Apart from that, Africa is experiencing a serious problem with antibiotics residues in its foodstuffs. An extensive review concluded that in some African countries, the prevalence of veterinary drugs contained in foodstuffs amounted to up to $94 \%$ in certain countries. This may affect both the food-processing industry (e.g., fermented dairy products) and the consumer alike [19]. This shows that food safety in Africa is a very immanent problem.

This condition becomes even more complicated. On one hand, traditional food habits have changed in Africa, creating products not clearly addressed in the current legislation. As an example, for Western Africa, not only the total amount of food required has increased, but consumers' preferences have shifted to convenience products, consuming more perishable products, and a growing awareness of food quality issues [20]. Improving policy coordination and policy implementation are, in fact, two of the key recommendations the aforementioned authors give to modernize the Western African food sector.

On the other hand, the "modernization" of traditional foods does not always improve their quality. As traditional food production has experienced labor ease by means of mechanization of e.g., cutting and grating processes, the production increase has not lead to a growing awareness of food safety, good manufacturing practices, and poor hygiene. Selling food that requires a certain degree of air circulations in tight-sealing plastic bags may also affect the quality by favoring the growth of microaerophilic or even anaerobial flora [17]. Since insects are traditional foodstuffs, these risks may also apply to them.

The degree of entomophagy also varies across the continent. Table 3 shows the different amounts of REIS per country, and while insect consumption may be rather unimportant in e.g., Djibouti or São Tomé and Príncipe, in Botswana, Benin, or Madagascar it plays a larger role. Besides and strictly speaking, introducing an edible species from one African nation to another where the consumption is unknown would make this species a novel food as coined in UEMOA, Niger, or EU regulation.

Another important issue is to tell food safety from food security. Strictly speaking, food security refers to the supply with (any kind of) food (in any quality), while food safety, in contrast, means to provide a foodstuff in a quality that does not compromise the consumer's health, i.e., free of pathogens, toxic substances, foreign bodies, radiation, etc. In many countries, food security is considered more important, particularly in those in that climate and other factors may lead to food shortages. However, AU documents include food safety in food security. Given the importance of food insects in times of the year when food is scarce (the rainy season, time before harvest, etc. [21]), the lacking of the consideration of insects still remains interesting. A possible reason is the fact that a certain portion of the current food legislation originates from colonial times, and the omission of edible insects in the first place may be part of the entomophobia of the colonial rulers. In fact, many people in Europe still consider eating insects either disgusting or a staple for the poor and primitive that cannot afford any "true" food" [22], although these concepts do not, by any chance, reflect the reality. In fact, this seems to be one of the major reasons why entomophagy is still not more popular in Europe, despite corresponding awareness campaigns.

All in all and in comparison to other areas of the world, food safety regulation in many African countries appears scarce or even not existing. One possible explanation may be the fact that governments were forced to focus on food security rather than food safety in response to natural catastrophes and warfare. However, as international African documents exposed here showed, the idea that food security mandatorily has to include food safety is becoming increasingly attended. Besides, the AU has underlined that poor food safety is not only a problem for the population (with 91 million cases 
of food-borne diseases in Africa per year and 137,000 casualties related to them) but also a problem decreasing the competitiveness of African agriculture inside and outside the continent [23]. The goals formulated in the Malabo Declaration to end hunger in Africa by 2025 will not be reached if food safety is left unattended. In response to that, the first FAO/WHO/AU International Food Safety Conference was held in Addis Ababa in February of 2019, and edible insects were addressed in one session [24], underlining the need to establish concrete policies also with regard to farming insects since the absence of specific regulations may trigger the establishment of insect farms that use-in terms of food safety-unsafe substrates, e.g., slaughterhouse wastes. The ideas raised in Addis Ababa were presented again at a subsequent meeting in Geneva in April of 2019, where the need of harmonizing food safety regulation was stressed [25].

Taking up the misleading conceptions that appear in Western societies on entomophagy, the reality in Africa is, at least locally and seasonally, a huge variety of vivid entomophagous traditions, far from being an "emergency foodstuff" (Figures 1 and 2). Most government bodies interviewed directly consider this tradition, tolerating the consumption and the trade with these animals, even though no concise framework exists. Table 4 showed that most African countries work with foodstuff definitions that permit the inclusion of edible insects, although they may not have been considered at the moment of publishing the corresponding regulations. This is a positive fact, and future framework can be based on these definitions. The will of some of the interview partners to fill this legal gap is also a promising perspective.

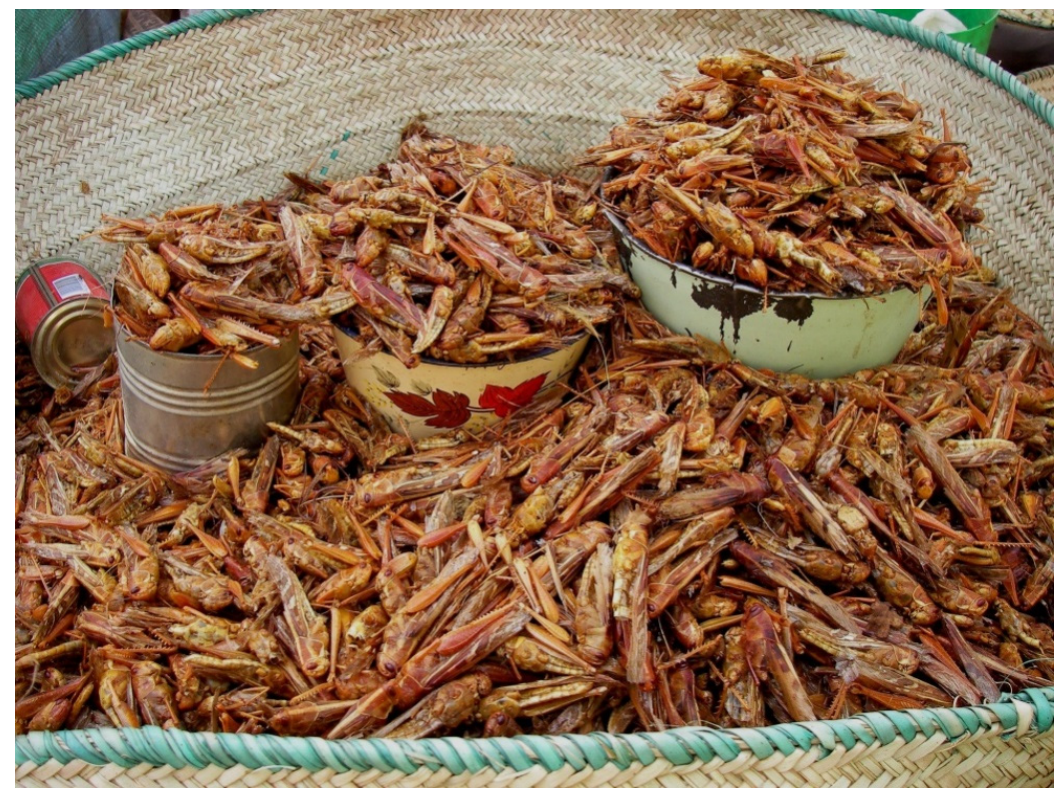

Figure 1. Fried locusts sold on a Western African market (image by S. Tchibozo).

This was also confirmed by the minutes of a meeting of several governmental and non-governmental organisations (GO and NGO) from in and outside Africa, held in Kenya [26]. One of the meeting's goals was to create awareness of the importance of the insect sector and the need to establish a corresponding legislation, which ideally could be harmonized among countries to ensure a comparable quality. These regulations should include both food safety standards and best practice codes. The future will show what will become of this initiative. 


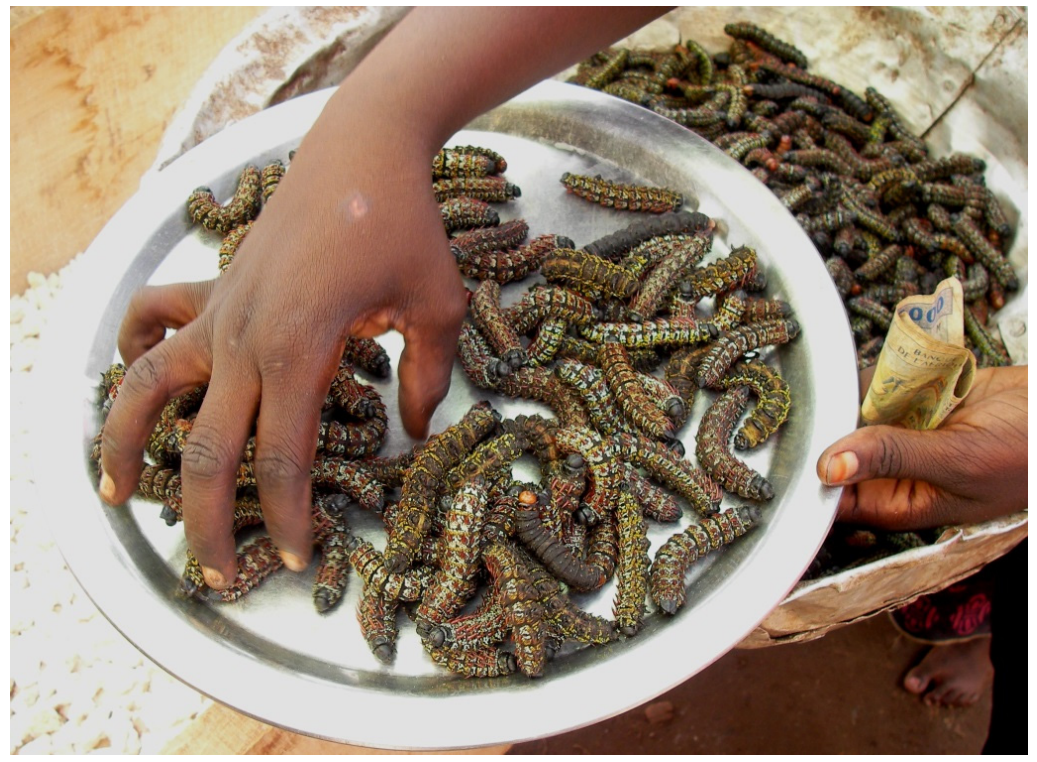

Figure 2. Living caterpillars sold on a Central African Market (image by S. Tchibozo).

\subsection{Food Insects Obtained from the Wild}

Following the tradition, insects have been caught from the wild in order to be processed and consumed [5]. African wildlife management legislations referring to hunting and/or natural resource management (as that of forests) usually base themselves on "wildlife" definitions that do include insects. In this context, and strictly speaking of law, this can result as a disadvantage, particularly in the moment of hunting respectively gathering them. As in the food law, the application of wildlife management laws to insects may result by mere extrapolation as the regulations were written while having traditional livestock or game species in mind. In those, using some trapping and hunting techniques is clearly banned. However, they do apply to what the definitions understand as "wildlife", and so, light traps, which are typically used to attract insects in the night, may be in fact illegal. The same is true for the permits many regulations request. It may be expected that, except phane in Botswana, gathering edible insects from the wild will be done without asking for these permits, perhaps because it is a traditional way of eating and earning money, perhaps because insects do not have the perceived relevance as cattle or high-priced game species.

Still, forest and wildlife management offer an interesting way to use the insect resource in a sustainable way. These species may be managed in their corresponding biotopes. This, however, requires the awareness that only sustainable use of these insects will ensure a longer-lasting income, rather than exterminating a species by over-harvesting. For this, reliable data on the degree to which a population may be extracted without endangering its survival are necessary, and this data used to be inexistent for insects. Only local gatherers may have this knowledge out of their experience.

In any way, Table 5 shows a large degree of variation among countries. Some allow wildlife management, some do not, and some regulations only refer to specific animal or product groups. Due to the complexity of this issue, it is highly recommended to study the actual situation in a given country intensively before any major uses of insects are made. Tchibozo et al. [27] summarize the necessary requirements to use wild populations thoroughly:

- Good knowledge of the edible species of a given region;

- Thorough species inventory of the area in question;

- Identification of the edible species;

- Good knowledge of the species' biology including their host plants;

- Detection of breeding sites;

- Detection of places where they are/can be modified. 
With knowledge, the particular breeding behavior and the feasibility for production can be assessed. This model is laid out for satisfying a local market and is the base of obtaining a solid colony for breeding in captivity, with the option of selling the offspring also abroad [27].

Besides, food safety concerns remain, since forest-derived foodstuffs are even less subjected to quality controls than livestock-derived ones are. Although tradition is prone to cope with traditional food safety problems like spoilage or pathogens, more modern risks as contaminants like insecticides are likely to pass undetected. Besides, modern storage methods like plastic bags also may impair the quality of insect products sold on the market.

A special situation is those species of insects that are edible and a pest at the same time. The idea of consuming edible pest insects is more than tempting, particularly since many of these species have a better nutritional profile that than the crops they feed on. To give an example, teff (Eragrostis tef) is a typical East African crop, and contains $12 \mathrm{~g}$ of protein/100 $\mathrm{g}$ dry matter (value calculated from Baye [28], while orthopterans range between 41 and $91 \mathrm{~g} / 100 \mathrm{~g}$ dry matter [6]. Using pest insects may be beneficial from the nutritional point of view opening up a new food resource; it reduces the damage to the crops and is, by itself, part of the environmental management of a given area. Legally, this may be difficult as many countries have established corresponding legislations to combat them. This applies mainly to locusts, but also to other species, as can be seen in Tables 7-10. From the food safety point of view however, the proper use of this food resource will depend fundamentally on the toxicological status of these animals (pesticides) and the possibility to process these animals right after harvesting into a storable product with a stable quality. In fact, orthopterans killed by insecticides are sometimes gathered and sold on West African markets [5].

Finally, some countries protect some native insect species from usage, e.g., Cape Verde and Djibouti, including some that are edible. This is a regular proceeding to protect the national fauna, particularly if the territory is relatively small and, in the case of Cape Verde, a set of island relatively far off the continental coast.

Thus, managing edible insects in the wild is an ancient tradition. However, a sound legal system to ensure sustainability will be necessary to make a larger use of edible insects.

\subsection{Insect Farming}

When wildlife management may be difficult because of legal uncertainties and food safety concerns, farming them may be an option [4]. Southeast Asian countries like Thailand, Cambodia, Laos, and Myanmar have started a larger attempt to rear insects and produce them as "mini-livestock" [29]. Two so-called Thai Agricultural standards that deal with crickets (TAS 8202-2017) and silkworms (TAS 8201/2012) are examples on how insect farming is regulated by the government. This option is basically also open to African countries.

From the legal point of view, livestock regulations in Africa are even scarcer than food-related ones and refer, if available at all, exclusively to classical and local domestic species.

Some countries allow wildlife respectively game farms, and if definitions fit, they could be nominally also applied to insects (Table 5). However, the choice of indigenous farmed species must be done carefully in order not to infringe any species protection, wildlife management, or pest control regulation (see above). Bringing foreign productive species (certain cricket and mealworm species or the black soldier fly) into the country may also be hazardous and may infringe on other nature protection or trading laws.

Raheem et al. [4] mention first insect farms for the black soldier fly (Hermetia illucens) in South Africa (which in fact is the largest in the world) and Nigeria, but for feed production. Edible crickets are reared in Kenya and Uganda. This implies that at least in those two countries, the setup of these farms was legal. 


\section{Conclusions}

In this way, asking for food quality standards for edible insects may be challenging if some countries have not addressed food quality standards for meat, fish, or dairy products so far. However, the world progresses, and Africa is a part of the global community just like any other region of the world is, and if foodstuffs' quality will be addressed in the future, those for edible insects should be included. The regulatory framework should address the entire production chain, starting from two different points of primary production, i.e., wildlife resource and farmed insects.

Regarding gathering from the wild, many African countries already have a solid legal base that could be applied to insects. However, population control is vital in order to protect existing natural populations. For food safety, the quality of the gathered animals is critical, particularly in terms of residues and contaminants, and harvested animals should be tested on a regular base, e.g., using Codex Alimentarius recommendations.

The possibility of farming insects in Africa must be assessed thoroughly, taking care not to interfere with land ownership, limited possibilities of using a given area, and, if applicable, farming regulations for livestock and/or wildlife. Animal species' protection, animal imports, and pest legislation must also enter this evaluation. The farmer must be able to control the life cycle of the farmed species. Special care must be taken to avoid the escape of the farmed insects respectively the entry of insect predators into the farm. Once established, a farm ensures food quality by providing a controlled environment to the farmed animals, from the materials used for construction and bedding to the feedstuffs. This is where residues and contaminants can also enter the production chain of a farm. Farms should also be evaluated on a regular base, e.g., to obtain a certificate that it works according to the national requirements. During these evaluations, the inspectors should pay special attention to animal welfare, meaning that the five freedoms also apply to farming insects. Whenever possible, farming must be done according to national law.

Regardless the origin of the harvested animals, killing must be done according to the animal welfare state-of-the-art procedures, which currently is freezing them or mushing them quickly in a blender. As soon as possible, insects must be heated thoroughly (e.g., $100{ }^{\circ} \mathrm{C}$ for $10 \mathrm{~min}$ ) to reduce bacterial counts, and rinsed. Storage of merely cooked insects must be in the refrigerator or an ice box, or, better, frozen. Insects preserved by other methods, e.g., drying, smoking, or fermenting can be stored traditionally. However, microbial counts should be assessed for these products in order to provide best-before dates for the consumer. Besides, general hygiene rules also apply to insects just as any other foodstuff.

In terms of public health surveillance, insects sold publicly, regardless if gathered or farmed, should be included in regular monitoring programs. There is no need to treat insect-based products any differently as more established foodstuffs are. Appropriate labeling follows national guidelines and should, by any chance, show the name of the insect (ideally including the scientific name), a best-before date and the information about allergens; all insects contain tropomyosin, which may lead to cross reactions of patients that are allergic to dust (mites) and crustaceans. Laboratory analyses should focus, on one hand, on the gross chemical composition (this may change from batch to batch if feeding regime was changed between batches), antibiotics (using substance specific tests rather than generic inhibitory ones as many insects contain innate inhibitors, which could lead to false-positive results), residues, and contaminants. The other focus is microbiology, with salmonellae, listeriae, total bacterial counts, coagulase-positive staphylococci, Escherichia coli and other Enterobacteriaceae, presumptive Bacillus cereus, yeasts, and fungi as the most important parameters, plus the ones established in national food law. 
Author Contributions: Conceptualization, N.T.G. and S.T.; Methodology, N.T.G. and S.T.; Software, N.T.G., S.T., A.A., F.A., M.M.G., and W.A.A.S.; Validation, S.T., A.A., F.A., M.M.G., W.A.A.S., and M.P.; Formal Analysis, N.T.G.; Investigation, N.T.G., S.T., A.A., F.A., M.M.G., and W.A.A.S.; Resources, N.T.G., S.T., M.P.; Data Curation, N.T.G.; Writing-Original Draft Preparation, N.T.G.; Writing-Review and Editing, S.T., A.A., F.A., M.M.G., W.A.A.S., and M.P.; Visualization, S.T.; Supervision, N.T.G., S.T., and M.P.; Project Administration, N.T.G.; Funding Acquisition, M.P. and N.T.G. All authors have read and agreed to the published version of the manuscript.

Funding: This research was funded by Deutsche Forschungsgemeinschaft and University of Veterinary Medicine Hannover, Foundation within the funding programme Open Access Publishing.

Acknowledgments: The authors wish to express their gratitude to Bernard Cole (Australia, for South Africa) and Jessy Kamwi (Namibia), Embassy of the Central African Republic in Paris, and all contributors from the authors' networks.

Conflicts of Interest: The authors declare no conflict of interest.

\section{Appendix A}

\section{Regulation Documents:}

(Note: in bi or trilingual texts, the order is from left to right; enumeration is strictly alphabetical and numerical)

Algeria

- Décret exécutif $n^{0}$ 91-53 relatif aux conditions d'hygiène lors du processus de la mise à la consommation des denrées alimentaires. http://www.fao.org/faolex/results/details/en/c/LEXFAOC004085.

- Décret exécutif no 95-387 du 5 Rajab 1416 correspondant au 28 novembre 1995 fixant la liste des ennemis des végétaux et les mesures de surveillance et de lutte qui leur sont applicables. (JORA N ${ }^{\circ} 73$ du 29-11-1995). http://www.fao.org/faolex/results/details/en/c/LEX-FAOC043461.

- Loi no $14-07$ du 13 Chaoual 1435 correspondant au 9 aout 2014 relative aux ressources biologiques. http://www.fao.org/faolex/results/details/en/c/LEX-FAOC171802.

- Loi no 87-17 du Ier août 1987 relative à la protection phytosanitaire. http://www.fao.org/faolex/ results/details/en/c/LEX-FAOC003579.

Angola

- Decreto Presidencial 179/18 - Aprova o Regulamento sobre a Sujeição a Análises Laboratoriais dos Produtos Destinados ao Consumo Humano e Animal. http://www.fao.org/faolex/results/details/ en/c/LEX-FAOC178359.

- Lei no 6/17 - Lei de bases de florestas e fauna salvagem. http://www.fao.org/faolex/results/details/ en/c/LEX-FAOC162520.

Benin

- Arrêté interministériel $\mathrm{n}^{\circ} 128 \mathrm{MDR} / \mathrm{MF} / \mathrm{DC} / \mathrm{CC} / \mathrm{CP}$ relatif au contrôle phytosanitaire des végétaux et des produits végétaux à l'importation et à l'exportation. http://www.fao.org/faolex/results/ details/en/c/LEX-FAOC007526.

- Décret no 92-258 fixant les modalités d'application de la Loi no 91-004 du 11 février 1991 portant réglementation phytosanitaire. http://www.fao.org/faolex/results/details/en/c/LEX-FAOC002350

- Loi no 84-009 du 15 mars 1984 sur le contrôle des denrées. http://www.fao.org/faolex/results/ details/en/c/LEX-FAOC086098.

- Loi no 91-004 portant réglementation phytosanitaire. http://www.fao.org/faolex/results/details/en/ c/LEX-FAOC002349.

- Loi $n^{0}$ 2002-16 du 18 octobre 2004 portant régime de la faune enRépublique du Bénin. http://www.fao.org/faolex/results/details/en/c/LEX-FAOC166784. 
- African convention on the conservation of nature and natural resources. http://www.fao.org/ faolex/results/details/en/c/LEX-FAOC045449.1

Botswana

- Agricultural Resources Conservation (Utilization of Veld Products) Regulations. http://www.fao. org/faolex/results/details/en/c/LEX-FAOC091414.

- Food Control Act. http://www.fao.org/faolex/results/details/en/c/LEX-FAOC066060.

- Locusts Act (Chapter 35:03). http://www.fao.org/faolex/results/details/en/c/LEX-FAOC006483.

- Plant Protection Act 2007 (Chapter 35:02). http://www.fao.org/faolex/results/details/en/c/LEXFAOC126405.

- Wildlife Conservation and National Parks Act. http://www.fao.org/faolex/results/details/en/c/LEXFAOC004728.

Burkina Faso

- Décret no 96-061/PRES/PM/MEE/MATS/MEFP/MCIA/MTT portant réglementation de l'exploitation de la faune au Burkina Faso. http://www.fao.org/faolex/results/details/en/c/LEX-FAOC004885.

- Loi no 003-2011/AN portant Code forestier au Burkina Faso. http://www.fao.org/faolex/results/ details/en/c/LEX-FAOC106703.

- Loi $\mathrm{n}^{\mathrm{o}}$ 025-2017/AN du 15 mai 2017 portant protection des végétaux au Burkina Faso. http://www.fao.org/faolex/results/details/en/c/LEX-FAOC171520.

Burundi

- Décret-loi no 1/033 portant protection des végétaux au Burundi. http://www.fao.org/faolex/results/ details/en/c/LEX-FAOC004668.

- Loi $\mathrm{N}^{\circ} 1 / 7$ du 15 juillet portant Révision du Code Forestier. http://www.fao.org/faolex/results/ details/en/c/LEX-FAOC163753.

- Loi $\mathrm{N}^{\circ}$ 1/17 du 10 septembre 2011 portant Commerce de Faune et de Flore Sauvages. http://www.fao.org/faolex/results/details/en/c/LEX-FAOC162986.

- Ordonnance no 53/agri - assistance dans la lutte contre les invasions de sauterelles et de criquets. http://www.fao.org/faolex/results/details/en/c/LEX-FAOC039378.

Cameroon

- Loi no 2003/03 portant protection phytosanitaire. http://www.fao.org/faolex/results/details/en/c/ LEX-FAOC050036.

Cape Verde

- Decreto Legislativo n ${ }^{0}$ 3/2009. http://www.fao.org/faolex/results/details/en/c/LEX-FAOC097520.

- Decreto-Regulamentar n ${ }^{\circ}$ 7/2002. http://www.fao.org/faolex/results/details/en/c/LEX-FAOC051798.

- $\quad$ Lei no 29/VIII/2013. http://www.fao.org/faolex/results/details/en/c/LEX-FAOC123988.

- Portaria no 37/2015 de 13 de Agosto. http://www.fao.org/faolex/results/details/en/c/LEX-FAOC148050.

Central African Republic

- Loi $\mathrm{n}^{\mathrm{O}}$ 03-04 du 20 janvier 2003 portant Code d'hygiène en République centrafricaine. http://www.fao.org/faolex/results/details/en/c/LEX-FAOC176540.

- Loi no 08/022 portant Code forestier de la République Centrafricaine. http://www.fao.org/faolex/ results/details/en/c/LEX-FAOC107432. 
- Loi n ${ }^{0}$ 62-350 relative à l'organisation de la protection des végétaux en République centrafricaine. http://www.fao.org/faolex/results/details/en/c/LEX-FAOC007180.

Chad

- Décret $\mathrm{n}^{\mathrm{o}}$ 10/PR/MA/99 fixant les modalités d' application de la loi $\mathrm{n}^{\circ}$ 14/PR/95 relative à la protection des végétaux. http://www.fao.org/faolex/results/details/en/c/LEX-FAOC126372.

- Loi no 005/PR/2007 du 16 avril 2007 portant création d'une Agence Nationale de Lutte Antiacridienne (ANLA). http://www.fao.org/faolex/results/details/en/c/LEX-FAOC180033.

- Loi no 14/PR/95 relative à la protection des végétaux. http://www.fao.org/faolex/results/details/en/ c/LEX-FAOC004040.

- Loi $\mathrm{n}^{\mathrm{O}}$ 14/PR/2008 portant régime de forêts, de la faune et de ressource halieutiques. http://www.fao.org/faolex/results/details/en/c/LEX-FAOC117920.

\section{COMESA}

- COMESA treaty amended by council meeting 2009. https://www.comesa.int/comesa-treaty/.

\section{COMIFAC}

- Traité relatif à la conservation et à la gestion durable des ecosystème forestiers d'Afrique Centrale et instituant la Commission de Forêts d'Afrique Centrale (COMIFAC). http://www.fao.org/faolex/ results/details/en/c/LEX-FAOC071928.

\section{Comoros}

- Code de la santé publique et de l'action sociale pour le bien être de la population - Loi no 95-013 du 24 juin 1995. http://droit-afrique.com/upload/doc/comores/Comores-Code-1995-sante-publique.pdf.

- Décret du 24 juin 1903 relatif aux mesures à prendre en cas de maladie contagieuse et parasitaire des plantations. http://droit-afrique.com/upload/doc/comores/Comores-Decret-1903-maladie-des-plantations.pdf.

- Loi-cadre no 94-018 relative à l'environnement. http://www.fao.org/faolex/results/details/en/c/ LEX-FAOC011718.

Congo-Brazzaville

- Loi n ${ }^{\circ}$ 48/83 du 21/04/1983 définissant les conditions de la conservation de et de l'exploitation de la faune sauvage. http://www.fao.org/faolex/results/details/en/c/LEX-FAOC004177.

- Loi n n $^{\circ}$-1256 du 26 novembre 1952 relative à l'organisation de la protection des végétaux dans les territoires relevant du Ministère de la France d'outre-mer. http://www.fao.org/faolex/results/ details/en/c/LEX-FAOC161165.

Congo-Kinshasa

- Arrêté interministériel no 003/CAB/MIN/ECN-EF/2006 et nº 099/CAB/MIN/FINANCES/2006 du 13 juin 2006 portant fixation des taux des droits, taxes et redevances à percevoir, en matière de faune et de flore, à l'initiative du ministère de l'environnement, conservation de la nature, eaux et forêts. http://www.fao.org/faolex/results/details/en/c/LEX-FAOC071929.

- Arrêté $\mathrm{n}^{\circ}$ 014/CAB/MIN/ENV/2004 du 29 avril 2004 relatif aux mesures d'exécution de la loi n 82-002 du 28 mai 1982 portant réglementation de la chasse. http://www.fao.org/faolex/results/ details/en/c/LEX-FAOC061848.

- Décret $\mathrm{n}^{\circ}$ 05/162 du 18 novembre 2005 portant réglementation phytosanitaire en République Démocratique du Congo.

- Loi $n^{\circ}$ 82-002 portant réglementation de la chasse. http://www.fao.org/faolex/results/details/en/c/ LEX-FAOC004275. 
- $\quad$ Loi no 11-2002 portant Code forestier. http://www.fao.org/faolex/results/details/en/c/LEX-FAOC034383.

Djibouti

- Décret no 2004-0065/PR/MHUEAT portant protection de la biodiversité. http://www.fao.org/faolex/ results/details/en/c/LEX-FAOC046297.

- Loi $\mathrm{n}^{\circ}$ 43/AN/83/1re L portant modification de l'article 1er de la délibération $\mathrm{n}^{\circ}$ 268/7 L du 3 avril 1971 portant interdiction totale de la chasse sur toute l'étendue du territoire. http://www.fao.org/faolex/results/details/en/c/LEX-FAOC004183.

EAC

- EAC food security action plan (2011-2015). https://www.eac.int/index.php? option=com_documentmananger\&task $=$ download.document\&file $=$ bWFpb19kb2N1bWVud HNfcGRmX2pLRWtST2pEalpSeE1qQ2pzeWlkVkRNRUFDIEZvb2QgU2VjdXJpdHkgQWN 0aW9uIFBsYW4=\&counter=109.

\section{ECCAS}

- Treaty establishing the Economic Community of Central African States. https:/www.wipo.int/ edocs/lexdocs/treaties/en/eccas/trt_eccas.pdf.

\section{ECOWAS}

- Revised treaty. Abuja, Nigeria, http://www.ecowas.int/wp-content/uploads/2015/01/Revisedtreaty.pdf.

\section{Egypt}

- 1966 قانون الزراعة رقم 53 لسنة (Law Nr. 53 of 1966: Promulgation of the Agriculture Law), extwprlegs1.fao.org > docs > pdf > egy153081.

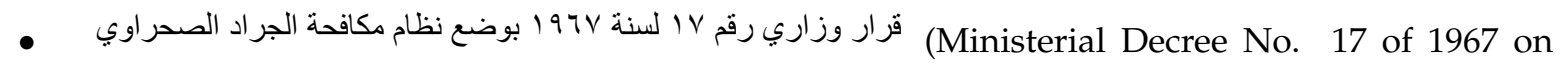
establishing a system to control the Desert Locust). http://www.fao.org/faolex/results/details/en/c/ LEX-FAOC122033.

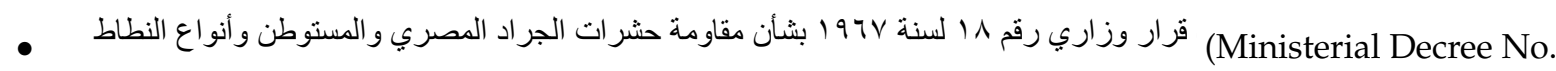
18 of 1967 on the Egyptian locust resistance and the types of hoppers). http://www.fao.org/faolex/ results/details/en/c/LEX-FAOC122031.

- Law No. 1/2017 on Promulgating National Food Safety Authority Law. http://nfsa.gov.eg/Images/ App_PP/DeskTop/App_Web/1/MyWebMedia/PDF/NFSA\%20Law-English.pdf.

- Law No. 102 of 1983 on Natural Protected Areas. http://www.fao.org/faolex/results/details/en/c/ LEX-FAOC020777.

Equatorial Guinea

- Ley n. ${ }^{o}$ 8/1.988, de fecha 31 de diciembre, Reguladora de la Fauna Silvestre, Caza y Áreas Protegidas. http://www.endangeredspecieslaws.com/endangered-species-laws-of-equatorial-guinea/.

Eritrea

- Forestry and Wildlife Conservation and Development Proclamation (No. 155/2006). http://www.fao.org/faolex/results/details/en/c/LEX-FAOC068045.

- Plant Quarantine Proclamation (No. 156/2006). http://www.fao.org/faolex/results/details/en/c/ LEX-FAOC068047. 
Eswatini

- Environmental Management Act 2002 (Act No. 5 of 2002). http://www.fao.org/faolex/results/ details/en/c/LEX-FAOC047833.

- $\quad$ Plant Control Act, 1981. http://www.fao.org/faolex/results/details/en/c/LEX-FAOC078838.

- Veterinary Public Health Act. http://www.gov.sz/images/veterinary\%20public\%20health\%20act_ \%202013.pdf.

Ethiopia

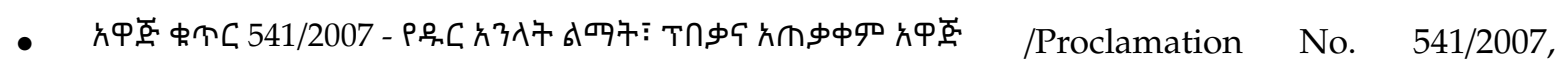
a Proclamation to Provide for the Development [sic!] Conservation and Utilization of Wildlife. http://www.fao.org/faolex/results/details/en/c/LEX-FAOC095249.

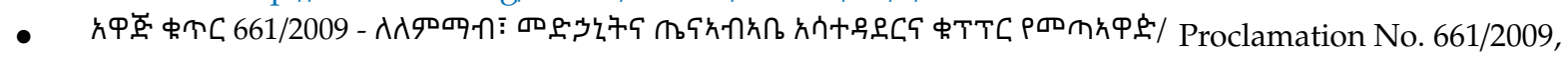
a proclamation to provide for food, medicine, and health care administration and control. http://www.fao.org/faolex/results/details/en/c/LEX-FAOC094419.

EU

- Commission Regulation (EC) No 2073/2005 of 15 November 2005 on microbiological criteria for foodstuffs (Text with EEA relevance). https://eur-lex.europa.eu/legal-content/EN/TXT/?uri=celex\% 3A32005R2073.

- Regulation (EC) No 178/2002 of the European Parliament and of the Council of 28 January 2002 laying down the general principles and requirements of food law, establishing the European Food Safety Authority and laying down procedures in matters of food safety. https://eur-lex.europa.eu/ legal-content/EN/TXT/HTML/?uri=CELEX:32002R0178\&from=DE.

- Regulation (EU) 2015/2283 of the European Parliament and of the Council of 25 November 2015 on novel foods, amending Regulation (EU) No 1169/2011 of the European Parliament and of the Council and repealing Regulation (EC) No 258/97 of the European Parliament and of the Council and Commission Regulation (EC) No 1852/2001 (Text with EEA relevance). https://eur-lex.europa.eu/eli/reg/2015/2283/oj.

- Risk profile related to production and consumption of insects as food and feed https://www.efsa. europa.eu/en/efsajournal/pub/4257.

- Ref. Ares(2019)382900 - 23/01/2019: Annex to the Commission Regulation (EU) .../... amending Annex III to Regulation (EC) No 853/2004 of the European Parliament and of the Council as regards specific hygiene requirements for insects intended for human consumption [sic]. https://ec.europa.eu/info/law/better-regulation/have-your-say/initiatives/2079Specific-hygiene-rules-for-insects-intended-for-human-consumption.

Gabon

- Décret no 18/PR/MEFEPEPN du 6 janvier 2005 fixant les conditions de création d'unités d'élevage d'espèces animales sauvages. http://www.fao.org/faolex/results/details/en/c/LEX-FAOC143387/.

- Décret no 692/PR/MEFEPEPN du 24 août 2004 fixant les conditions d'exercice des droits d'usage coutumiers en matière de forêt, de faune, de chasse et de pêche. http://www.fao.org/faolex/results/ details/en/c/LEX-FAOC174469/.

- Loi n ${ }^{\circ}$ 016-01 portant code forestier en République gabonaise. http://www.fao.org/faolex/results/ details/en/c/LEX-FAOC029255/.

\section{GAFTA}

- Economic and Social Council (Ed., 1997):, قرار المجلس الاقتصادبإعلان منطقة التجارة الحرة العربية الكبرى 1997/2/19 والاجتماعى رقم 1317 د.ع 59 بتاريخ 19 .http://www.aproarab.com/Down/Etfaqiat/Ar/EtfaqiatAr4.doc. 3 pp. 
Gambia

- Biodiversity and Wildlife Act, 2003. http://www.fao.org/faolex/results/details/en/c/LEXFAOC158129.

- National Environment Management Act, 1994 (NEMA). http://www.fao.org/faolex/results/details/ en/c/LEX-FAOC006275.

- Plant Importation and Regulation Act. http://www.fao.org/faolex/results/details/en/c/LEXFAOC041167.

Ghana

- Plants and Fertilizer Act, 2010 (No. 803). http://www.fao.org/faolex/results/details/en/c/LEXFAOC168842.

- Public Health Act, 2012 (Act No. 851 of 2012). http://www.fao.org/faolex/results/details/en/c/LEXFAOC136559.

- Wild Animal Preservation Act, 1961. http://www.fao.org/faolex/results/details/en/c/LEXFAOC040827.

- Wildlife Conservation Regulations, 1971. http://www.fao.org/faolex/results/details/en/c/LEXFAOC040817.

Guinea

- Loi L/92/027/CTRN instituant le contrôle phytosanitaire des végétaux à l'importation et à l'exportation. http://www.fao.org/faolex/results/details/en/c/LEX-FAOC004005.

- Loi U97/038/An du 9 Decembre Adoptant et promulguant Ie Code de Protection de la faune sauvage et Réglementation de la Chasse. http://www.fao.org/faolex/results/details/en/c/LEX-FAOC01273.

Guinea-Bissau

- Decreto $n^{0}$ 62-E/92 do 30 Dezembro: Regime do Controlo Sanitário dos Géneros Alimentícios. http://www.fao.org/faolex/results/details/en/c/LEX-FAOC016119.

- $\quad$ Decreto-Lei no 2/2004. http://www.fao.org/faolex/results/details/en/c/LEX-FAOC012733.

- Decreto-Lei n $n^{0}$ 5/2011. http://www.fao.org/faolex/results/details/en/c/LEX-FAOC118220.

- Decreto-Lei $n^{0}$ 4/99 Define as medidas de protecção fitossanitárias destinadas a evitar a introdução no Pais de organismos prejudiciais aos vegetais ou produtos vegetais. http://www.fao.org/faolex/ results/details/en/c/LEX-FAOC023411.

IGAD

- IGAD Regional Strategy, Volume 1: the framework. https://igad.int/documents, 84 pp.

- IGAD Regional Strategy, Volume 2: implementation plan 2016-2020. https://igad.int/documents, $124 \mathrm{pp}$.

IvoryCoast

- Décret no 92-487 du 26 août 1992 portant étiquetage et présentation des denrées alimentaires. http://www.fao.org/faolex/results/details/en/c/LEX-FAOC178128.

- Loi no 64-490 du 21 décembre 1964 relative à la protection des végétaux. http://www.fao.org/ faolex/results/details/en/c/LEX-FAOC175761.

- Loi no 65-225 relative à la protection de la faune et à l'exercice de la chasse. http://www.fao.org/ faolex/results/details/en/c/LEX-FAOC089113.

- Loi no 94-442 portant modification de la loi nº 65-225 relative à la protection de la faune et à l'exercice de la chasse. http://www.fao.org/faolex/results/details/en/c/LEX-FAOC089114. 
Kenya

- Food, Drugs and Chemical Substances Act. http://www.fao.org/faolex/results/details/en/c/LEXFAOC106440.

- Plant Protection Act (Cap. 324). http://www.fao.org/faolex/results/details/en/c/LEX-FAOC018403.

- Plant Protection Order (Cap. 324). http://www.fao.org/faolex/results/details/en/c/LEX-FAOC018406.

- Plant Protection Rules (Cap. 324). http://www.fao.org/faolex/results/details/en/c/LEX-FAOC018416.

- Wildlife Conservation and Management Act, 2013, No. 47 of 2013. http://www.fao.org/faolex/results/ details/en/c/LEX-FAOC134375.

Lesotho

- Historical Monuments, Relics, Fauna and Flora Act, Act 41 of 1967. http://www.fao.org/faolex/ results/details/en/c/LEX-FAOC041401.

- Locust Destruction Proclamation (No. 3 of 1925). http://www.fao.org/faolex/results/details/en/c/ LEX-FAOC128717.

Liberia

- Agricultural Law (Title 3 of the Revised Liberian Code of Laws). http://www.fao.org/faolex/results/ details/en/c/LEX-FAOC005338.

- New Wildlife and National Parks Act. http://www.fao.org/faolex/results/details/en/c/LEXFAOC003548.

- Public Health Law - Title 33 - Liberian Code of Laws Revised. http://www.fao.org/faolex/results/ details/en/c/LEX-FAOC174510.

Libya

- انانون رقم 27 لسنة 1968 بشأن وقاية النباتات. Law No. 27 of 1968 on the protection of plants. http://www. fao.org/faolex/results/details/en/c/LEX-FAOC046426.

Madagascar

- Décret $n^{0}$ 2017-064 du 31 du janvier 2017 Portant création et organisation du Centre de Lutte Antiacridienne de Madagascar (IFVM). http://www.fao.org/faolex/results/details/en/c/LEXFAOC171287.

- Ordonnance $\mathrm{n}^{\circ}$ 86-013 relative à la législation phytosanitaire à Madagascar. http://www.fao.org/ faolex/results/details/en/c/LEX-FAOC007459.

- Ordonnance $n^{\circ}$ 60-126 du 3 Octobre1960. http://www.fao.org/faolex/results/details/en/c/LEXFAOC004210.

Malawi

- National Parks and Wildlife Act (Act No. 11 of 1992). http://www.fao.org/faolex/results/details/en/ c/LEX-FAOC004733.

- Plant Protection Act, 1969 (No. 11 of 1969). http://www.fao.org/faolex/results/details/en/c/LEXFAOC063795.

Mali

- Décret no 06-259/P-RM du 3 juin 2006 instituant l'autorisation de mise sur le marché des denrées alimentaires, des aliments pour animaux et des additifs alimentaires. http://www.fao.org/faolex/ results/details/en/c/LEX-FAOC153390. 
- Loi $n^{0}$ 02-013 du 03 juin 2002 Instituant le contrôle phytosanitaire en République du Mali. http://www.fao.org/faolex/results/details/en/c/LEX-FAOC153268.

- Loi no 06-065 du 29 décembre 2006 portant création du Centre National de Lutte Contre le Criquet Pèlerin. http://www.fao.org/faolex/results/details/en/c/LEX-FAOC158047.

- Loi n ${ }^{\circ}$ 2018-036/ du 27 juin 2018 fixant les principes de la gestion de la faune et de son habitat. http://www.fao.org/faolex/results/details/en/c/LEX-FAOC180235.

Mauritania

- Arrêté $\mathrm{n}^{\mathrm{o}} \mathrm{R}-0031257$ du 12 novembre 2002 fixant la liste des organismes de quarantaine. http://www.fao.org/faolex/results/details/en/c/LEX-FAOC138454.

- Décret $\mathrm{n}^{\mathrm{o}} 2002-062$ du 25 juillet 2002 portant application de la loi 042-2000 du 26 juillet 2000 relative à la protection des végétaux. http://www.fao.org/faolex/results/details/en/c/LEX-FAOC086852.

- Loi no 97-006 abrogeant et remplaçant la loi n 75-003 du 15 janvier portant la chasse et de la protection de la nature. http://www.fao.org/faolex/results/details/en/c/LEX-FAOC010273.

- Loi no 2000-042 relative à la protection des végétaux. http://www.fao.org/faolex/results/details/en/ c/LEX-FAOC061959.

Mauritius

- Food Act 1998 (Act No. 1 of 1998). http://www.fao.org/faolex/results/details/en/c/LEXFAOC028943.

- Native Terrestrial Biodiversity and National Parks Act 2015 (No. 14 of 2015). http://www.fao.org/ faolex/results/details/en/c/LEX-FAOC161113.

- Plant Protection Act (Act No. 10 of 2006). http://www.fao.org/faolex/results/details/en/c/LEXFAOC074277.

Morocco

- Arrêté conjoint du ministre de l'agriculture et de la pêche maritime et du ministre de l'intérieur $\mathrm{n}^{\mathrm{o}}$ 287-09 du 30 janvier 2009 édictant des mesures d'urgence destinées à la lutte contre le Charançon rouge du palmier (Rhynchophorusferrugineus). http://www.fao.org/faolex/results/details/en/c/LEXFAOC092510.

- Dahir du 20 septembre 1927 (23 rebia I 1346) portant règlement de police sanitaire des végétaux en zone française de l'Empire Chérifien. http://www.fao.org/faolex/results/details/en/c/LEXFAOC178301.

- Loi n $n^{0}$ 28-07 relative à la sécurité sanitaire des produits alimentaires. http://www.fao.org/faolex/ results/details/en/c/LEX-FAOC096767.

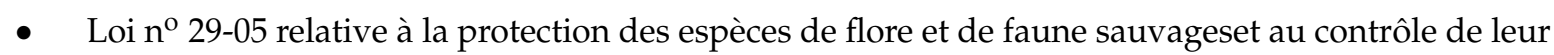
commerce. http://www.fao.org/faolex/results/details/en/c/LEX-FAOC106726.

- Loi n ${ }^{\circ}$ 57-02 portant approbation, quant au principe, de la ratification du Royaume du Maroc de I' Accord portant création d'une Commission de lutte contre le criquet pèlerin dans la région occidentale, fait à Rome en novembre 2000. http://www.fao.org/faolex/results/details/en/c/LEXFAOC171836.

Mozambique

- Decreto $n^{0}$ 5/2009 de 29 de Dezembro. http://www.fao.org/faolex/results/details/en/c/LEXFAOC112022.

- Decreto $n^{0}$ 5/2009 de 1 de Junho. http://www.fao.org/faolex/results/details/en/c/LEX-FAOC112020.

- Decreto $n^{\circ}$ 15/2006 - Regulamento sobre os Requisitos Higiénico-Sanitários de Produção, Transporte, Comercialização e Inspecção e Fiscalização dos Géneros Alimentícios, http://www.fao. org/faolex/results/details/en/c/LEX-FAOC110946. 
- Lei no 10/99 - establece os princípios e normas básicos sobre a protecção, conservação e utilização sustentável dos recursos florestais e faunísticos. http://www.fao.org/faolex/results/details/en/c/ LEX-FAOC020106.

Namibia

- Foodstuffs, Cosmetics and Disinfectants Ordinance 18 of 1979 - Ordinance to control the sale, manufacture and importation of foodstuffs, cosmetics and disinfectants; and to provide for incidental matters. https://laws.parliament.na/cms_documents/foodstuffs,-cosmetics-anddisinfectants-a17dca6f1d.pdf.

- Nature Conservation Ordinance, 1975. http://www.fao.org/faolex/results/details/en/c/LEXFAOC018007.

- Plant Quarantine Act, 2008 (No. 7 of 2008). http://www.fao.org/faolex/results/details/en/c/LEXFAOC094398.

- Regulations relating to the Destroying of Locusts (GN no. 30 of 1989). http://www.fao.org/faolex/ results/details/en/c/LEX-FAOC188741.

Niger

- Arrêté $n^{0}$ 13/MDA/DPV du 11 février 2005, portant création et organisation du projet de lutte d'urgence contre le criquet pèlerin. http://www.fao.org/faolex/results/details/en/c/LEXFAOC065246.

- Décret $\mathrm{n}^{0}$ 2011-616/PRN/MEL du 25 novembre 2011 réglementant l'inspection d'hygiène des denrées animales et des denrées alimentaires d'origine animale. http://www.fao.org/faolex/results/ details/en/c/LEX-FAOC176645.

- Loi no 98-07 fixant le régime de la chasse et de la protection de la faune. http://www.fao.org/faolex/ results/details/en/c/LEX-FAOC080736.

- Loi no 2015-35 du 26 mai 2015 relative à la protection des végétaux. http://www.fao.org/faolex/ results/details/en/c/LEX-FAOC175085.

Nigeria

- Agriculture (Control of Importation) Act. http://www.fao.org/faolex/results/details/en/c/LEXFAOC120040.

- Forest Law. http://www.fao.org/faolex/results/details/en/c/LEX-FAOC003330.

- $\quad$ Forest Regulations. http://www.fao.org/faolex/results/details/en/c/LEX-FAOC003331.

- Food and Drugs (Amendment) Decree 1999, Decree No. 21, http://www.fao.org/faolex/results/ details/en/c/LEX-FAOC034264.

- Wild Animals Law. http://www.fao.org/faolex/results/details/en/c/LEX-FAOC041660.

Rwanda

- Itegeko $\mathrm{n}^{\mathrm{0}} 16 / 2016$ ryo ku wa 10/05/2016 rigena uburyo bwo kurengera ubuzima bw'ibimera mu Rwanda/Law $N^{\circ} 16 / 2016$ of 10/05/2016 on plant health protection in Rwanda/Loi $N^{\circ} 16 / 2016$ du 10/05/2016 portant protection de la santé des végétaux au Rwanda. http://www.fao.org/faolex/ results/details/en/c/LEX-FAOC188020.

- Itegeko $\mathrm{n}^{\mathrm{o}} 47 / 2012$ ryo $\mathrm{ku}$ wa 14/01/2013 rigenga imicungire n'igenzura ry'ibiribwa n'imiti/Law No 47/2012 of 14/01/2013 relating to the regulation and inspection of food and pharmaceutical products/Loi No 47/2012 du 14/01/2013 portant règlementation et inspection des produits alimentaires et pharmaceutiques. http://www.fao.org/faolex/results/details/en/c/LEXFAOC131821. 
- Itegeko $n^{\circ} 70 / 2013$ ryo ku wa 07/09/2013 rigenga urosobe rw'ibinyabuzima mu Rwanda/Law $n^{\circ}$ 70/2013 of 07/09/2013 governing biodiversity in Rwanda/Loi n 70/2013 du 07/09/2013 régissant la biodiversité au Rwanda. http://www.fao.org/faolex/results/details/en/c/LEX-FAOC131764.

SADC

- Dar-es-Salam declaration on agriculture and food security in the SADC region. https://www.sadc. int/documents-publications/show/813.

- Protocol on wildlife conservation and law enforcement. https://www.sadc.int/documentspublications/show/824.

- Regional guidelines for the regulation of food safety in SADC member states. https://www.sadc. int/documents-publications/show/4087.

São Tomé \& Príncipe

- Decreto Lei no 5/2016 Aprova a Lei-quadro de Sanidade Vegetal. http://www.fao.org/faolex/results/ details/en/c/LEX-FAOC160888.

Seychelles

- Food Act, 2014 (No. 8 of 2014). http://www.fao.org/faolex/results/details/en/c/LEX-FAOC143993.

- Plant Protection Act 1996 (Cap. 171A). http://www.fao.org/faolex/results/details/en/c/LEXFAOC007782.

Sierra Leone

- Act No. 23, 1960, Public Health Ordinance. http://www.fao.org/faolex/results/details/en/c/LEXFAOC181412.

- Wildlife Conservation Act, 1972. http://www.fao.org/faolex/results/details/en/c/LEX-FAOC041659.

Somalia

- Veterinary Law Code - 2016. http://www.fao.org/faolex/results/details/en/c/LEX-FAOC171698.

South Africa

- Agricultural Pests Act (No. 36). http://www.fao.org/faolex/results/details/en/c/LEX-FAOC107871.

- Control Measures Relating to Fall Armyworm (G.N. No. 449 of 2017). http://www.fao.org/faolex/ results/details/en/c/LEX-FAOC167448.

- Foodstuffs, Cosmetic, and Disinfectants Act No. 54 of 1972. http://www.fao.org/faolex/results/ details/en/c/LEX-FAOC085626.

- National Forests Act. http://www.fao.org/faolex/results/details/en/c/LEX-FAOC123699.

Sudan

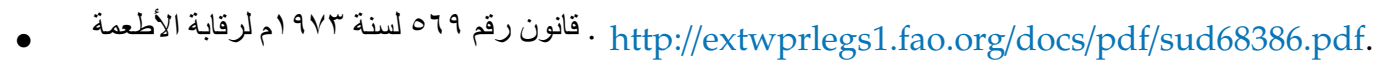

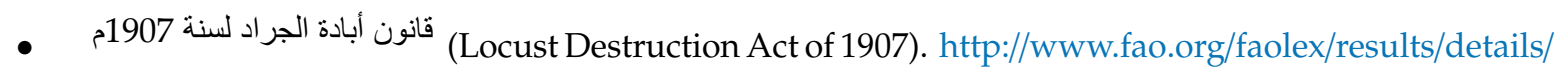
en/c/LEX-FAOC027490.

Tanzania

- Plant Protection Act (No. 13 of 1997). http://www.fao.org/faolex/results/details/en/c/LEXFAOC019688. 
- Tanzania Food, Drugs, and Cosmetics Act. http://www.fao.org/faolex/results/details/en/c/LEXFAOC053027.

- Wildlife Conservation Act, 2008. http://www.fao.org/faolex/results/details/en/c/LEX-FAOC097858.

Thailand

- Thai Agricultural Standard TAS 8201/2012 - Good practices for silk cocoon production. http://web.acfs.go.th/eng/system_standard.php?pageid=6

- Thai Agricultural Standard TAS 8202/2017 - Good agricultural practices for cricket farm. http://web.acfs.go.th/eng/system_standard.php?pageid=9

Togo

- Loi no 2008-09 portant Code Forestier. http://www.fao.org/faolex/results/details/en/c/LEXFAOC085011.

Tunisia

• قانون عدد 25 لسنة 2019 مؤرخ في 26 فيفري 2019 يتعلق بالسلامة الصحية للمواد الغذائية وأغذية الحيوانات http://www.legislation.tn/detailtexte/Loi-num-2019-25-du----jort-2019-024_2019024000251.

- Arrêté du Ministre de l'agriculture du 31 mai 2012, fixant la liste des organismes de quarantaine. http://www.fao.org/faolex/results/details/en/c/LEX-FAOC113265.

- Décret $n^{\circ}$ 88-1751 fixant l'organisation et les modalités de fonctionnement de la campagne de lutte anti-acridienne.

- Loi n 20 portant Code forestier. http://www.fao.org/faolex/results/details/en/c/LEX-FAOC002805.

- Loi no 92-72 portant refonte de la législation relative à la protection des végétaux. http://www.fao. org/faolex/results/details/en/c/LEX-FAOC011737.

\section{UEMOA}

- Règlement $\mathrm{n}^{\mathrm{o}}$ 007/2007/CM/UEMOA relatif à la sécurité sanitaire des végétaux, des animaux et des aliments dans l'UMEOA. http://www.droit-afrique.com/upload/doc/uemoa/UEMOA-Reglement2007-07-securite-sanitaire.pdf.

Uganda

- Plant Protection and Health Act (Cap. 31). http://www.fao.org/faolex/results/details/en/c/LEXFAOC158615.

- The Food and Drugs Act, Chapter 27. http://www.fao.org/faolex/results/details/en/c/LEXFAOC096144.

- Uganda Wildlife Statute, 1996. http://www.fao.org/faolex/results/details/en/c/LEX-FAOC009000.

Zambia

- Plant Pests and Diseases Act (Cap. 233). http://www.fao.org/faolex/results/details/en/c/LEXFAOC046759.

- Plant Pests and Diseases (Pests and Alternate Hosts) Order (Cap. 233). http://www.fao.org/faolex/ results/details/en/c/LEX-FAOC046785.

- Plant Pests and Diseases (Pest Control) Regulations (Cap. 233). http://www.fao.org/faolex/results/ details/en/c/LEX-FAOC046784.

- The Food and Drugs Act, Chapter 303. http://www.fao.org/faolex/results/details/en/c/LEXFAOC048635. 
Zimbabwe

- Food and Food Standards Act, Chapter 15:04. http://www.fao.org/faolex/results/details/en/c/LEXFAOC024975.

- Locust Control Act [Chapter 19:06]. http://www.fao.org/faolex/results/details/en/c/LEX-FAOC060738.

- Plant Pests and Diseases Act [Chapter 19:08]. http://www.fao.org/faolex/results/details/en/c/LEXFAOC060741.

\section{References}

1. Amadi, E.N.; Kiin-Kabari, D.B. Nutritional composition and microbiology of some edible insects commonly eaten in Africa, hurdles and future prospects: A critical review. J. Food Microbiol. Saf. Hyg. 2016, 1, 107. [CrossRef]

2. Jideani, A.I.O.; Nethsiheni, R.K. Selected edible insects and their products in traditional medicine, food and pharmaceutical industries in Africa: Utilization and prospects. In Future Foods; Mikkola, H., Ed.; IntechOpen: London, UK, 2017; pp. 55-69. Available online: https://www.intechopen.com/books/future-foods/selectededible-insects-and-their-products-in-traditional-medicine-food-and-pharmaceutical-industrie (accessed on 15 April 2020).

3. Kelemu, S.; Niassy, S.; Torto, B.; Fiaboe, K.; Affognon, H.; Tonnag, H.; Maniania, N.K.; Ekesi, S. African edible insects for food and feed: Inventory, diversity, commonalities and contribution to food safety. J. Insects Food Feed 2015, 1, 103-119. [CrossRef]

4. Raheem, D.; Carrascosa, C.; Oluwole, O.B.; Nieuwland, M.; Saraiva, A.; Millán, R.; Raposo, A. Traditional consumption of and rearing edible insects in Africa, Asia and Europe. Crit. Rev. Food Sci. Nutr. 2018, 59, 2169-2188. [CrossRef] [PubMed]

5. Tchibozo, S.; Lecoq, M. Edible Orthoptera from Africa: Preservation and promotion of traditional knowledge. Metaleptea 2017, 37, 24-29.

6. Huis, A. Insects as food in Sub-Saharan Africa. Int. J. Trop. Insect Sci. 2003, 23, 163-185. [CrossRef]

7. Grabowski, N.T.; Ahlfeld, B.; Lis, K.A.; Jansen, W.; Kehrenberg, C. The current legal status of edible in Europe. BMTW 2019, 132, 295-311.

8. De-Magistris, T.; Pascucci, S.; Mitsopoulos, D. Paying to see a bug on my food: How regulations and information can hamper radical innovations in the European Union. Br Food J. 2015, 117, 1777-1792. [CrossRef]

9. Halloran, A.; Vantomme, P.; Hanboonsong, Y.; Ekesi, S. Regulating edible insects: The challenge of addressing food security, nature conservation, and the erosion of traditional food culture. Food Sec. 2015, 7, 739-746. [CrossRef]

10. Lähteenmäki, A.; Grmelová, N.; Hénoult-Ethier, L.; Deschamps, M.-H.; Vandenberg, G.W.; Zhao, A.; Zhang, Y.; Yang, B.; Nemane, V. Insects as food and feed: Laws of the European Union, United States, Canada, Mexico, Australia, and China. EFFL 2017, 12, 22-36.

11. Jongema, Y. List of Edible Insects of the World; Wageningen University and Research: Wageningen, The Netherlands, 2017; Available online: https://www.wur.nl/en/Research-Results/Chair-groups/PlantSciences/Laboratory-of-Entomology/Edible-insects/Worldwide-species-list.htm (accessed on 15 April 2020).

12. Commission de l'Ocean Indien (COI). Conférence des Bailleurs Sur la Sécurité Alimentaire Dans L'indianocéanie. Available online: https://www.commissionoceanindien.org/conference-des-bailleurs-lacommunaute-internationale-sengage-aux-cotes-de-la-commission-de-locean-indien-coi-pour-la-securitealimentaire-dans-lindianoceanie/ (accessed on 15 April 2020).

13. Vink, N.; Sandrey, R. Chapter 8: Regional integration in SACU's agricultural sector. In Monitoring Regional Integration of Southern Africa Yearbook; Trade Law Centre for Southern Africa: Western Cape, South Africa, 2009; pp. 165-189. Available online: https://www.kas.de/wf/doc/kas_20303-544-2-30.pdf (accessed on 15 April 2020).

14. Agricultural Trade Forum (ATF). Namibia Food Safety Policy. Available online: https://www.atf.org.na/ issues/article.php?blogID=27 (accessed on 15 April 2020).

15. Djankla, M.T. Analyse de la Législation Vétérinaire Togolaise Relative à la Santé Publique au Regard des Lignes Directrices de l'OIE. Master's Thesis, Université Cheik Anta Diop de Dakar, Dakar, Senegal, 2011; 32p. 
16. Direction Générale de la Faune et des Aires Protegées. Plan d' Actions National sur l'Utilisation Durable de la Faune Sauvage par les Populations Locales au Gabon 2017-2019. Available online: http://www.fao.org/ faolex/results/details/en/c/LEX-FAOC178881/ (accessed on 15 April 2020).

17. Oguntoyinbo, F.A. Safety challenges associated with traditional foods in West Africa. Food Rev. Int. 2014, 30, 338-358. [CrossRef]

18. Kussaga, J.B.; Jacxses, L.; Tiisekwa, B.P.M.; Luning, P.A. Food safety management systems performance in African food processing companies: A review of deficiencies and possible improvement strategies. J. Sci. Food Agric. 2013, 94, 2154-2169. [CrossRef] [PubMed]

19. Mensah, S.E.P.; Koudané, O.D.; Sanders, P.; Laurentie, M.; Mensah, G.A.; Abiola, F.A. Résidus d'antibiotiques et denrées d'origine animale en Afrique: Risques de santé publique. Rev. Sci. Tech. Off. Int. Epiz 2014, 33, 975-986. [CrossRef]

20. Staatz, J.; Hollinger, F. West African Food Systems and Changing Consumer Demands; West African Papers 4; OECD Publishing: Paris, France, 2016; 23p.

21. Huis, A. Edible insects contributing to food security? Agric. Food Secur. 2015, 4. [CrossRef]

22. Grabowski, N.T. Speiseinsekten; Behr's Verlag: Hamburg, Germany, 2017; 77p.

23. AU. Food Safety coordination and tracking on the agenda at a side meeting of the 14th CAADP Partnership Platform. 2018. Available online: https://au.int/en/pressreleases/20180425/food-safety-coordination-andtracking-agenda-side-meeting-14th-caadp (accessed on 15 April 2020).

24. Binder, E.V. Alternative food and feed products. In Proceedings of the First FAO/WHO/AU International Food Safety Conference, Addis Ababa, Ethiopia, 12-13 February 2019; IFSC-1/19/TS2.5. Available online: https://www.who.int/docs/default-source/resources/bp-alternative-food-and-feed-products.pdf (accessed on 15 April 2020).

25. Anon. Thematic briefing: Promoting harmonized food safety regulation in a time of change, innovation, and globalized trade. In Proceedings of the Future of Food Safety-International Conference on Food Safety, Geneva, Switzerland, 23-24 April 2019; Available online: https://www.who.int/docs/default-source/resources/ promoting-harmonized-food-safety-regulation-en.pdf?sfvrsn=6ce81d24_2 (accessed on 15 April 2020).

26. GREEiNSECT. Report on International Conference on Legislation and Policy on the Use of Insects as Food and Feed in East Africa, the Vic Hotel, Kisumu, Kenya, 2-3 March 2016. Available online: https:/www.google.com/url?sa=t\&rct=j\&q=\&esrc=s\&source=web\&cd=1\&cad=rja\&uact=8\& ved=2ahUKEwijhrDY0cHlAhXHUxUIHVZRBVkQFjAAegQIAhAC\&url=https\%3A\%2F\%2Fgreeinsect.ku.dk\% 2Fevents\%2FConference_Report.pdf\&usg=AOvVaw1o7CZ840MQpbsf1yo2WIaG (accessed on 15 April 2020).

27. Tchibozo, S.; Malaisse, F.; Mergen, P. Insectes consommés par l'homme en Afrique occidentale francophone. Geo-Eco-Trop 2017, 40, 105-114.

28. Nutrient Composition and Health Benefits. Ethiopia Strategy Support Program Working Paper \# 67, Addis Abeba/ETH. Available online: http://ebrary.ifpri.org/cdm/ref/collection/p15738coll2/id/128334 (accessed on 15 April 2020).

29. Hanboonsong, Y.; Jamjanya, T.; Durst, P. Six-Legged Livestock-Edible Insect Farming, Collecting and Marketing in Thailand; FAO_-Regional Office for Asia and the Pacific: Bangkok, Thailand, 2013; 57p.

(C) 2020 by the authors. Licensee MDPI, Basel, Switzerland. This article is an open access article distributed under the terms and conditions of the Creative Commons Attribution (CC BY) license (http://creativecommons.org/licenses/by/4.0/). 